\title{
Altered gene expression in cells from patients with lysosomal storage disorders suggests impairment of the ubiquitin pathway
}

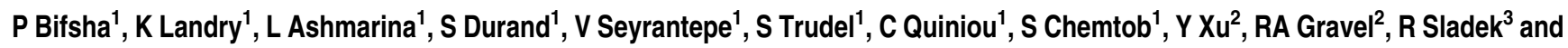 \\ AV Pshezhetsky ${ }^{* 1}$
}

By comparing mRNA profiles in cultured fibroblasts from patients affected with lysosomal storage diseases, we identified differentially expressed genes common to these conditions. These studies, confirmed by biochemical experiments, demonstrated that lysosomal storage is associated with downregulation of ubiquitin C-terminal hydrolase, UCH-L1 in the cells of eight different lysosomal disorders, as well as in the brain of a mouse model of Sandhoff disease. Induction of lysosomal storage by the cysteine protease inhibitor E-64 also reduced UCH-L1 mRNA, protein level and activity. All cells exhibiting lysosomal storage contained ubiquitinated protein aggregates and showed reduced levels of free ubiquitin and decreased proteasome activity. The caspase-mediated apoptosis in E-64-treated fibroblasts was reversed by transfection with a UCH-L1 plasmid, and increased after downregulation of UCH-L1 by siRNA, suggesting that UCH-L1 deficiency and impairment of the ubiquitin-dependent protein degradation pathway can contribute to the increased cell death observed in many lysosomal storage disorders.

Cell Death and Differentiation (2007) 14, 511-523. doi:10.1038/sj.cdd.4402013; published online 4 August 2006

A genetically determined deficiency of lysosomal enzymes and proteins, or of proteins involved in lysosomal biogenesis, results in lysosomal storage disorders (LSD), characterized by the accumulation of partially undegraded catabolic products in the lysosomes leading to their increased size and number. This severely affects cell turnover causing malfunction of many tissues and organs, and in particular leads to hepatosplenomegaly, corneal clouding, skeletal deformation and central nervous system degeneration. Although rapid progress has been achieved in revealing the genetic basis of many LSD, much less is known about the mechanisms underlying the disruption of cell metabolic and signalling pathways associated with these conditions. Despite the broad variability of LSD, diseases that store similar types of macromolecules (sphingolipids, mucopolisaccharides or glycoproteins) often have similar biochemical, pathological and clinical phenotypes, suggesting that the nature and distribution of the stored material is the major lesion-defining factor. However, some cellular pathological features are common even between different major classes of LSD. For example, in many cases lysosomal storage is accompanied by the appearance of ubiquitinated protein aggregates. Previous studies have demonstrated that $20-30 \%$ of small and motor neurons of patients affected with Tay-Sachs disease, Niemann-Pick disease and Hunter disease showed antiubiquitin immunoreactivity in contrast to the cells of normal controls. ${ }^{1}$ The cells of animal models of MPS VII, ${ }^{2}$ NiemannPick disease ${ }^{3}$ and prosaposin deficiency ${ }^{4}$ also contain ubiquitinated protein aggregates. Monoubiquitination is now considered one of the major signals that targets transmembrane proteins for lysosomal degradation (reviewed in Bonifacino and Traub $^{5}$ ), but the mechanism relating lysosomal storage and formation of ubiquitinated aggregates is not understood.

Another common feature among different classes of LSD is the increased occurrence of cell death. For example, high levels of apoptosis were detected in neurons, microglia and Purkinje cells of patients affected with Tay-Sachs disease, Globoid cell leukodystrophy (Krabbe disease), Nieman-Pick disease type $\mathrm{C}, \mathrm{G}_{\mathrm{M} 1}$-gangliosidosis, Gaucher disease and infantile neuronal ceroid lipofuscinosis. ${ }^{6-12}$ In addition, apoptosis of cartilage cells (chondrocytes) was detected in mucopolysaccharidosis (MPS) Type VI, ${ }^{13}$ while apoptosis of muscle cells leading to loss of cardiac muscle mass and cardiomyopathy was found in Pompe disease. ${ }^{14}$ Apoptosis was also observed in cultured cells of LSD patients, including fibroblasts and renal tubular epithelial cells from patients affected with cystinosis. ${ }^{15}$ In several cases, accumulated substrates of the deficient enzymes (such as psychosine in globoid cell leukodystrophy, or ceramide in Farber disease)

\footnotetext{
${ }^{1}$ Sainte-Justine Hospital and Departments of Pediatrics and Biochemistry, University of Montreal, Montreal, Canada; ${ }^{2}$ Department of Biochemistry \& Molecular Biology, University of Calgary, Calgary, Alberta, Canada and ${ }^{3}$ Department of Genetics, McGill University and Genome Quebec Innovation Centre, Montréal, Québec, Canada ${ }^{*}$ Corresponding author: AV Pshezhetsky, Service de génétique médicale, Hôpital Sainte-Justine, 3175 Côte Ste-Catherine, Montréal, Canada Qc H3T 1 C5. Tel: + 1514345 4931/2736; Fax: + 15143454766 ;

E-mail: alexei.pchejetski@umontreal.ca

Keywords: apoptosis; lysosomal storage disorders; proteosome; RNA arrays; Sandhoff disease; ubiquitin C-terminal hydrolase

Abbreviations: UCH-L1, ubiquitin C-terminal hydrolase 1; LSD, lysosomal storage disorders; MPS, mucopolysaccharidosis; SIASD, sialic acid storage disease; HEXB, lysosomal hexosaminidase B; LC, liquid chromatography; MS/MS, tandem mass spectroscopy; E-64, epoxysuccinyl-leucylamido-(4-guanidino) butane; LAMP-2, lysosome-associated membrane protein 2; GAD, gracile axonal dystrophy; mUb, monoubiquitin

Received 03.8.05; revised 26.5.06; accepted 13.6.06; Edited by RA Knight; published online 04.8.06
} 
were shown to be directly cytotoxic and to induce apoptosis (reviewed by Tardy et al. ${ }^{16}$ ). In other LSD, such as $\mathrm{G}_{\mathrm{M} 2^{-}}$and $\mathrm{G}_{\mathrm{M} 1}$-gangliosidoses and mucopolysaccharidoses I and IIIB, central nervous system apoptosis resulted from general inflammation (see for example Wada et al. ${ }^{17}$ and Mizukami et al. $^{18}$ ). Although there are examples of LSD not accompanied by increased cell death, these data suggest that apoptosis is a frequent event.

In this study, we investigated the link between impairment of the ubiquitin-dependent protein degradation pathway and the increased occurrence of programmed cell death in different classes of LSD. We evaluated the secondary changes in the transcriptome and the proteome of cultured skin fibroblasts from normal individuals and from LSD patients and observed that major ubiquitin C-terminal hydrolase, UCH-L1, was downregulated in the cells of eight different lysosomal disorders, as well as in the brain of a mouse model of Sandhoff disease. We also showed that the inhibition of lysosomal catabolism caused secondary deficiency of $\mathrm{UCH}$ $\mathrm{L} 1$ and that downregulation of $\mathrm{UCH}-\mathrm{L} 1$ directly induced caspase-mediated apoptosis. Taken together, our data suggest that the UCH-L1 deficiency and impairment of the ubiquitin-dependent protein degradation pathway can contribute to increased cell death in LSD.

\section{Results}

Secondary changes in the RNA expression patterns in the cells of LSD patients. To identify genes whose expression was altered by the presence of lysosomal storage products, we used oligonucleotide microarrays to compare mRNA transcript levels in cultured skin fibroblasts from normal individuals with those of fibroblasts obtained from patients affected with sialic acid storage disease (SIASD) or sialidosis. Although these conditions are caused by different primary genetic defects and result in the accumulation of different storage products, they are both characterized by significantly increased lysosome number and volume in many cell types. In confluent cultured skin fibroblasts, a three- to fivefold increase in the number of lysosomal storage bodies was detected by immunohistochemical staining with anti-LAMP-2 antibodies (Supplementary Figure 1) as well as by staining with a lysosome-specific dye, LysoTracker Red (not shown).

We selected three cell lines from LSD patients and three lines from normal controls to perform expression microarray analysis. All cell lines were passaged an equal number of times and had similar growth rates. RNA was pooled from three culture dishes for each line in order to minimize biological variation. A total of 53 probe sets, representing 43 known genes and six ESTs were differentially expressed in each of the three patient cell lines (Table 1). Many of the differentially regulated transcripts are consistent with previously described phenotypes of LSD cells. For example, the suppression of numerous proteins and enzymes involved in the formation of the extracellular matrix (transglutaminase 2; different types of collagen; tissue inhibitor of metalloproteinase 3; elastin; aggrecan 1; versican) correlates with the reduced ability of fibroblasts to form elastic fibers, as was shown for GM1-gangliosidosis, Morquio B disease, sialidosis and galactosialidosis (Hinek A., private communication).

On the other hand, the majority of differentially regulated transcripts identified in our microarray studies have not been previously reported in association with LSD (Table 1). This latter group includes ubiquitin C-terminal hydrolase L1 (UCHL1), a member of the deubiquitinating enzyme family presumably involved in ubiquitin recycling to maintain the pool of monomeric ubiquitin in the cell. Malfunction of the ubiquitin pathway due to the $\mathrm{UCH}-\mathrm{L} 1$ deficiency has previously been associated with neuronal degeneration in a small number of patients with autosomal dominant Parkinson's disease (PARK5). ${ }^{19}$ As neuronal death and dystrophy is also a characteristic feature in LSD, we wished to further characterize the relationship between decreased $\mathrm{UCH}-\mathrm{L} 1$ expression and LSD.

Expression of UCHL-1 in fibroblasts of patients affected with LSD. In order to confirm the suppression of UCH-L1 expression detected by the microarray experiments and to determine if the UCH-L1 expression was altered in cell lines obtained from patients affected with other LSD, we analyzed the level of UCH-L1 mRNA by real-time PCR in the cultured skin fibroblasts from five different healthy controls and from 11 patients affected with the following LSD: SIASD (1 line), sialidosis (2 lines), galactosialidosis (1 line), $\mathrm{G}_{\mathrm{M} 1^{-}}$ gangliosidosis (2 lines), Morquio syndrome type A (1 line) and $B$ (2 lines), and Gaucher disease (types I and II, one line each). These experiments (Figure 1a) demonstrated that the level of UCH-L1 mRNA in the affected cell lines was significantly reduced (mean $23.5 \%$, median $23 \%$ of normal) compared to an internal control (18S mRNA, data not shown).

The results of these expression studies were confirmed by several biochemical experiments. We performed immunohistochemical staining of UCH-L1 in normal fibroblasts and in the fibroblasts from the LSD patients. Anti-UCH-L1 immunofluorescence in the control skin fibroblasts showed a diffuse pattern consistent with the previously described cytoplasmic localization of the enzyme (Figure $1 \mathrm{~b}$ ). The cells of patients showed similar localization of $\mathrm{UCH}-\mathrm{L} 1$, but the intensity of staining was significantly reduced in all lines reflecting lower protein levels (Figure $1 \mathrm{~b}$ ). The amount of $\mathrm{UCH}-\mathrm{L} 1$ protein in the same cells was also estimated by Western blot using anti$\mathrm{UCH}-\mathrm{L} 1$ monoclonal antibodies (Figure 1c). We found a significantly reduced $(\sim 22 \%)$ intensity of the $25-\mathrm{kDa} \mathrm{im}-$ munoreactive UCH-L1 band normalized to the intensity of the control GAPDH band in the cells of LSD patients, which correlated well with the results of the expression studies.

In order to determine whether the alterations in UCH-L1 expression observed in the cultured patients cells might also happen in an animal model that has the ambiguity of the concomitant involvement of the inflammatory response, we assayed UCH-L1 mRNA level, ubiquitin hydrolase activity and $\mathrm{UCH}-\mathrm{L} 1$ protein in total brain extracts obtained from 3-month old mice in which the lysosomal hexosaminidase B (HEXB) gene has been inactivated by homologous recombination. ${ }^{20}$ Homozygous HEXB null mice (HEXB-/-) represent a reliable animal model of human Sandhoff disease and develop lysosomal storage bodies as well as a high rate of apoptosis 
Table 1 Major groups of proteins whose expression was changed in both SIASD and sialidosis fibroblasts

\begin{tabular}{|c|c|c|c|c|c|c|c|c|c|c|c|}
\hline & Probe set & Control 1 & Control 2 & Control 3 & Salla & Salla & Sialidosis & $\begin{array}{l}\text { Fold } \\
\text { change }\end{array}$ & Accession & Gene & Description \\
\hline \multirow[t]{9}{*}{$\begin{array}{l}\text { Cell adhesion } \\
\text { and extracellular } \\
\text { matrix }\end{array}$} & $\begin{array}{l}\text { 32112_s_at } \\
\text { 35829_at }\end{array}$ & $\begin{array}{r}29.8 \\
229.1\end{array}$ & $\begin{array}{r}9.5 \\
37.0\end{array}$ & $\begin{array}{r}14.4 \\
486.4\end{array}$ & $\begin{array}{r}425.6 \\
1600.5\end{array}$ & $\begin{array}{l}295.8 \\
912.8\end{array}$ & $\begin{array}{l}1852.5 \\
3214.4\end{array}$ & $\begin{array}{r}47.9 \\
7.6\end{array}$ & $\begin{array}{l}\text { Al800499 } \\
\text { AL080181 }\end{array}$ & $\begin{array}{l}\text { AIM1 } \\
\text { IGSF4 }\end{array}$ & $\begin{array}{l}\text { Absent in melanoma } 1 \\
\text { Immunoglobulin } \\
\text { superfamily, member } 4\end{array}$ \\
\hline & $\begin{array}{l}\text { 32193_at } \\
\text { 36917_at }\end{array}$ & $\begin{array}{l}131.1 \\
378.8\end{array}$ & $\begin{array}{r}23.5 \\
573.2\end{array}$ & $\begin{array}{l}116.0 \\
625.1\end{array}$ & $\begin{array}{l}1067.1 \\
2182.0\end{array}$ & $\begin{array}{r}398.5 \\
1072.3\end{array}$ & $\begin{array}{r}551.6 \\
1169.0\end{array}$ & $\begin{array}{l}7.5 \\
2.8\end{array}$ & $\begin{array}{l}\text { AF030339 } \\
\text { Z26653 }\end{array}$ & $\begin{array}{l}\text { PLXNC1 } \\
\text { LAMA2 }\end{array}$ & $\begin{array}{l}\text { Plexin C1 } \\
\text { Laminin, alpha } 2 \text { (merosin, } \\
\text { congenital muscular } \\
\text { dystrophy) }\end{array}$ \\
\hline & $\begin{array}{l}\text { 33127_at } \\
\text { 38077_at } \\
\text { 38126_at } \\
\text { 36513_at }\end{array}$ & $\begin{array}{r}5957.9 \\
8703.4 \\
40745.6 \\
2871.3\end{array}$ & $\begin{array}{r}1802.1 \\
8544.3 \\
37915.2 \\
2178.2\end{array}$ & $\begin{array}{r}5454.9 \\
9305.9 \\
49246.0 \\
2410.2\end{array}$ & $\begin{array}{r}11363.6 \\
12643.9 \\
30188.8 \\
974.3\end{array}$ & $\begin{array}{r}6772.6 \\
10759.1 \\
19650.4 \\
1479.0\end{array}$ & $\begin{array}{r}6670.5 \\
8965.9 \\
21133.1 \\
447.2\end{array}$ & $\begin{array}{r}1.9 \\
1.2 \\
-1.8 \\
-2.6\end{array}$ & $\begin{array}{l}\text { U89942 } \\
\text { X52022 } \\
\text { J04599 } \\
\text { U37283 }\end{array}$ & $\begin{array}{l}\text { LOXL2 } \\
\text { COL6A3 } \\
\text { BGN } \\
\text { MAGP2 }\end{array}$ & $\begin{array}{l}\text { Lysyl oxidase-like } 2 \\
\text { Collagen, type VI, alpha } 3 \\
\text { Biglycan } \\
\text { Microfibril-associated } \\
\text { glycoprotein-2 }\end{array}$ \\
\hline & 38636_at & 18696.3 & 15581.0 & 8226.3 & 3797.7 & 5990.7 & 6570.0 & -2.6 & AB003184 & ISLR & $\begin{array}{l}\text { Immunoglobulin } \\
\text { superfamily containing } \\
\text { leucine-rich repeat }\end{array}$ \\
\hline & 38112_g_at & 6571.3 & 9058.7 & 6721.1 & 1393.2 & 4184.7 & 2289.3 & -2.8 & X15998 & CSPG2 & $\begin{array}{l}\text { Chondroitin sulfate } \\
\text { proteoglycan } 2 \text { (versican) }\end{array}$ \\
\hline & 1034_at & 11826.4 & 16617.4 & 6886.4 & 4266.4 & 4018.2 & 3198.3 & -3.1 & U14394 & TIMP3 & $\begin{array}{l}\text { Tissue inhibitor of } \\
\text { metalloproteinase } 3 \\
\text { (Sorsby fundus dystrophy, } \\
\text { pseudoinflammatory) }\end{array}$ \\
\hline & 39333_at & 4733.7 & 4238.4 & 7949.4 & 716.5 & 1703.1 & 1834.4 & -4.0 & M26576 & COL4A1 & Collagen, type IV, alpha 1 \\
\hline & 39098_at & 8578.2 & 1542.5 & 3617.5 & 121.9 & 635.6 & 792.5 & -8.9 & X52896 & ELN & $\begin{array}{l}\text { Elastin (supravalvular } \\
\text { aortic stenosis, Williams- } \\
\text { Beuren syndrome) }\end{array}$ \\
\hline & 38965_at & 1864.1 & 1029.6 & 2129.1 & 214.9 & 29.7 & 62.7 & -16.3 & M55172 & AGC1 & $\begin{array}{l}\text { Aggrecan } 1 \text { (chondroitin } \\
\text { sulfate proteoglycan } 1 \text {, } \\
\text { large aggregating } \\
\text { proteoglycan) }\end{array}$ \\
\hline \multirow[t]{12}{*}{ Cell signalling } & 38545_at & 728.9 & 120.5 & 559.5 & 6840.9 & 2452.1 & 3243.7 & 8.9 & M31682 & INHBB & $\begin{array}{l}\text { Inhibin, beta } \mathrm{B} \text { (activin } \mathrm{AB} \\
\text { beta polypeptide) }\end{array}$ \\
\hline & 34335_at & 93.6 & 274.8 & 375.8 & 825.4 & 894.1 & 1810.5 & 4.7 & Al765533 & EFNB2 & Ephrin-B2 \\
\hline & $\begin{array}{l}\text { 39665_at } \\
\text { 37420_i_at }\end{array}$ & $\begin{array}{l}427.3 \\
660.2\end{array}$ & $\begin{array}{l}424.4 \\
150.9\end{array}$ & $\begin{array}{l}302.7 \\
677.0\end{array}$ & $\begin{array}{l}3021.8 \\
1621.5\end{array}$ & $\begin{array}{l}1173.4 \\
1007.6\end{array}$ & $\begin{array}{l}1227.9 \\
1340.7\end{array}$ & $\begin{array}{l}4.7 \\
2.7\end{array}$ & $\begin{array}{l}\text { U33267 } \\
\text { AL022723 }\end{array}$ & $\begin{array}{l}\text { GLRB } \\
\text { HLA-F }\end{array}$ & $\begin{array}{l}\text { Glycine receptor, beta } \\
\text { Major histocompatibility } \\
\text { complex, class I. F }\end{array}$ \\
\hline & $\begin{array}{l}\text { 41419_at } \\
\text { 38379_at }\end{array}$ & $\begin{array}{r}290.0 \\
3473.2\end{array}$ & $\begin{array}{r}244.1 \\
3633.3\end{array}$ & $\begin{array}{r}302.2 \\
3397.1\end{array}$ & $\begin{array}{r}1172.9 \\
11436.0\end{array}$ & $\begin{array}{r}644.4 \\
5949.4\end{array}$ & $\begin{array}{r}383.4 \\
8633.1\end{array}$ & $\begin{array}{l}2.6 \\
2.5\end{array}$ & $\begin{array}{l}\text { AL080142 } \\
\text { X76534 }\end{array}$ & $\begin{array}{l}\text { CED-6 } \\
\text { GPNMB }\end{array}$ & $\begin{array}{l}\text { CED-6 protein } \\
\text { Glycoprotein } \\
\text { (transmembrane) } \mathrm{nmb}\end{array}$ \\
\hline & 41123_s_at & 7281.0 & 6639.4 & 8029.9 & 4623.7 & 4970.5 & 2151.4 & -1.9 & L35594 & ENPP2 & $\begin{array}{l}\text { Ectonucleotide } \\
\text { pyrophosphatase/ } \\
\text { phosphodiesterase } 2 \\
\text { (autotaxin) }\end{array}$ \\
\hline & 2062_at & 10533.1 & 13086.2 & 16306.5 & 7146.8 & 5080.9 & 4494.4 & -2.4 & L19182 & IGFBP7 & $\begin{array}{l}\text { Insulin-like growth factor } \\
\text { binding protein } 7\end{array}$ \\
\hline & 33705_at & 1915.1 & 1012.6 & 1137.6 & 309.3 & 535.3 & 407.6 & -3.2 & L20971 & PDE4B & $\begin{array}{l}\text { Phosphodiesterase 4B, } \\
\text { cAMP-specific } \\
\text { (phosphodiesterase E4 } \\
\text { dunce homolog, } \\
\text { Drosophila) }\end{array}$ \\
\hline & $\begin{array}{l}\text { 1929_at } \\
\text { 38404_at }\end{array}$ & $\begin{array}{l}4753.7 \\
5428.6\end{array}$ & $\begin{array}{r}1430.8 \\
11488.9\end{array}$ & $\begin{array}{l}1573.8 \\
3179.2\end{array}$ & $\begin{array}{r}730.4 \\
1016.6\end{array}$ & $\begin{array}{r}476.3 \\
1505.5\end{array}$ & $\begin{array}{r}672.8 \\
2186.2\end{array}$ & $\begin{array}{l}-4.1 \\
-4.3\end{array}$ & $\begin{array}{l}\text { U83508 } \\
\text { M55153 }\end{array}$ & $\begin{array}{l}\text { ANGPT1 } \\
\text { TGM2 }\end{array}$ & $\begin{array}{l}\text { Angiopoietin } 1 \\
\text { Transglutaminase } 2 \text { (C } \\
\text { polypeptide, protein- } \\
\text { glutamine-gamma- } \\
\text { glutamyltransferase) }\end{array}$ \\
\hline & 32521_at & 18948.3 & 9071.5 & 13745.1 & 6453.1 & 673.8 & 768.5 & -5.3 & AF056087 & SFRP1 & $\begin{array}{l}\text { Secreted frizzled-related } \\
\text { protein } 1\end{array}$ \\
\hline & 38268_at & 643.2 & 449.4 & 491.7 & 55.1 & 21.3 & 116.4 & -8.2 & U08989 & SLC1A1 & $\begin{array}{l}\text { Solute carrier family } 1 \\
\text { (neuronal/epithelial high } \\
\text { affinity glutamate } \\
\text { transporter, system Xag), } \\
\text { member } 1\end{array}$ \\
\hline & 1495_at & 3188.1 & 1697.8 & 2818.0 & 419.1 & 135.5 & 281.7 & -9.2 & M34057 & LTBP1 & $\begin{array}{l}\text { Latent transforming } \\
\text { growth factor beta binding } \\
\text { protein } 1\end{array}$ \\
\hline & 39593_at & 1319.8 & 194.8 & 250.4 & 53.1 & 27.8 & 21.1 & -17.3 & Al432401 & FGL2 & Fibrinogen-like 2 \\
\hline \multirow[t]{2}{*}{ Cytoskeleton } & $\begin{array}{l}\text { 35729_at } \\
\text { 39542_at }\end{array}$ & $\begin{array}{l}1067.8 \\
3003.9\end{array}$ & $\begin{array}{r}510.9 \\
3120.3\end{array}$ & $\begin{array}{r}674.2 \\
2907.3\end{array}$ & $\begin{array}{l}3961.8 \\
1261.3\end{array}$ & $\begin{array}{l}2738.2 \\
1154.8\end{array}$ & $\begin{array}{l}1476.2 \\
1558.8\end{array}$ & $\begin{array}{r}3.6 \\
-2.3\end{array}$ & $\begin{array}{l}\text { AB018270 } \\
\text { AF059611 }\end{array}$ & $\begin{array}{l}\text { MYO1D } \\
\text { ENC1 }\end{array}$ & $\begin{array}{l}\text { Myosin ID } \\
\text { Ectodermal-neural cortex } \\
\text { (with BTB-like domain) }\end{array}$ \\
\hline & $\begin{array}{l}\text { 38800_at } \\
\text { 39063_at }\end{array}$ & $\begin{array}{r}10678.7 \\
3725.4\end{array}$ & $\begin{array}{r}3829.0 \\
20552.6\end{array}$ & $\begin{array}{r}2130.7 \\
16992.0\end{array}$ & $\begin{array}{r}1147.3 \\
167.0\end{array}$ & $\begin{array}{r}420.7 \\
2159.4\end{array}$ & $\begin{array}{r}944.5 \\
1311.0\end{array}$ & $\begin{array}{r}-6.6 \\
-11.3\end{array}$ & $\begin{array}{l}\text { D45352 } \\
\text { J00073 }\end{array}$ & $\begin{array}{l}\text { STMN2 } \\
\text { ACTC }\end{array}$ & $\begin{array}{l}\text { Stathmin-like } 2 \\
\text { Actin, alpha, cardiac } \\
\text { muscle }\end{array}$ \\
\hline \multirow[t]{2}{*}{$\begin{array}{l}\text { Protein } \\
\text { degradation }\end{array}$} & $\begin{array}{l}\text { 37391_at } \\
\text { 34182_at }\end{array}$ & $\begin{array}{l}6190.1 \\
2367.3\end{array}$ & $\begin{array}{l}5308.6 \\
2674.5\end{array}$ & $\begin{array}{l}5777.4 \\
1720.7\end{array}$ & $\begin{array}{r}21878.6 \\
5679.3\end{array}$ & $\begin{array}{l}7949.7 \\
3895.4\end{array}$ & $\begin{array}{l}8526.0 \\
4479.1\end{array}$ & $\begin{array}{l}2.2 \\
2.1\end{array}$ & $\begin{array}{l}X 12451 \\
\text { U18932 }\end{array}$ & $\begin{array}{l}\text { CTSL } \\
\text { NDST1 }\end{array}$ & $\begin{array}{l}\text { Cathepsin } \mathrm{L} \\
\mathrm{N} \text {-deacetylase/N- } \\
\text { sulfotransferase (heparan } \\
\text { glucosaminyl) } 1\end{array}$ \\
\hline & 36990_at & 5636.1 & 12166.4 & 4310.6 & 674.9 & 1834.2 & 1860.8 & -5.1 & X04741 & UCHL1 & $\begin{array}{l}\text { Ubbiquitin carboxyl- } \\
\text { terminal esterase L1 } \\
\text { (ubiquitin thiolesterase) }\end{array}$ \\
\hline
\end{tabular}


Table 1 (Continued)

\begin{tabular}{|c|c|c|c|c|c|c|c|c|c|c|c|}
\hline & Probe set & Control 1 & Control 2 & Control 3 & Salla & Salla & Sialidosis & $\begin{array}{c}\text { Fold } \\
\text { change }\end{array}$ & Accession & Gene & Description \\
\hline \multirow[t]{5}{*}{$\begin{array}{l}\text { Transcription } \\
\text { regulation }\end{array}$} & 36308_at & 355.1 & 186.4 & 13.6 & 1031.6 & 577.3 & 503.0 & 3.8 & D76435 & $\mathrm{ZIC} 1$ & $\begin{array}{l}\text { Zic family member } 1 \\
\text { (odd-paired homolog, } \\
\text { Drosophila) }\end{array}$ \\
\hline & 41448_at & 378.8 & 367.2 & 377.6 & 938.2 & 478.4 & 755.1 & 1.9 & AC004080 & HOXA10 & Homeo box A10 \\
\hline & 40674_s_at & 7930.4 & 3775.4 & 4470.5 & 1216.7 & 918.9 & 2157.5 & -3.8 & S82986 & $\mathrm{HOXC6}$ & Homeo box C6 \\
\hline & 39158_at & 4517.4 & 2239.8 & 1432.4 & 500.1 & 403.6 & 594.7 & -5.5 & AB021663 & ATF5 & $\begin{array}{l}\text { Activating transcription } \\
\text { factor } 5\end{array}$ \\
\hline & 33436_at & 3249.7 & 1680.1 & 4095.5 & 224.3 & 424.6 & 482.8 & -8.0 & Z46629 & sox9 & $\begin{array}{l}\text { SRY (sex determining } \\
\text { region Y)-box } 9 \\
\text { (campomelic dysplasia, } \\
\text { autosomal sex-reversal) }\end{array}$ \\
\hline \multirow[t]{7}{*}{ Other } & 40813_at & 539.4 & 396.2 & 282.8 & 2173.8 & 978.2 & 1543.4 & 3.9 & Al768188 & FLJ21243 fis & \multirow{7}{*}{$\begin{array}{l}\text { Homo sapiens cDNA: } \\
\text { FLJ21243 fis, clone } \\
\text { COL01164. } \\
\text { KIAA0802 protein } \\
\text { Kidney ankyrin repeat- } \\
\text { containing protein } \\
\text { Hypothetical protein } \\
\text { FLJ12443 } \\
\text { Hypothetical protein } \\
\text { FLJ22678 } \\
\text { Aldehyde dehydrogenase } \\
1 \text { family, member A3 } \\
\text { Homo sapiens mRNA; } \\
\text { cDNA DKFZp586L0120 } \\
\text { KIAA0626 gene product }\end{array}$} \\
\hline & $\begin{array}{l}\text { 39614_at } \\
\text { 37225_at }\end{array}$ & $\begin{array}{r}844.8 \\
1317.2\end{array}$ & $\begin{array}{r}646.8 \\
1123.9\end{array}$ & $\begin{array}{r}810.7 \\
1074.4\end{array}$ & $\begin{array}{r}2298.7 \\
651.9\end{array}$ & $\begin{array}{r}1529.2 \\
640.0\end{array}$ & $\begin{array}{r}2089.2 \\
892.1\end{array}$ & $\begin{array}{r}2.6 \\
-1.6\end{array}$ & $\begin{array}{l}\text { AB018345 } \\
\text { D79994 }\end{array}$ & $\begin{array}{l}\text { KIAA0802 } \\
\text { KANK }\end{array}$ & \\
\hline & 41177_at & 2181.1 & 2021.6 & 2443.2 & 1116.8 & 1371.8 & 736.6 & -2.1 & AW024285 & FLJ12443 & \\
\hline & 32566_at & 5700.5 & 5420.2 & 5543.2 & 1519.4 & 2369.2 & 2515.7 & -2.6 & AA165701 & FLJ22678 & \\
\hline & 36686_at & 2678.2 & 1064.5 & 2197.3 & 702.3 & 746.6 & 243.0 & -3.5 & U07919 & ALDH1A3 & \\
\hline & 38351_at & 667.4 & 291.7 & 516.2 & 45.1 & 157.4 & 125.4 & -4.5 & AL050154 & DKFZp586L0120 & \\
\hline & 33241_at & 1470.3 & 1001.8 & 1271.4 & 184.2 & 354.8 & 155.0 & -5.4 & AB014526 & KIAA0626 & \\
\hline
\end{tabular}

in neurons, microglia and Purkinje cells. ${ }^{6} \mathrm{We}$ found that $\mathrm{UCH}$ L1 mRNA was reduced to about $30 \%$ in homozygous mutant mice (HEXB-/-) as compared to their wild-type siblings $(\mathrm{HEXB}+/+)$. The mRNA levels in asymptomatic heterozygous siblings (HEXB $+/-$ ) were not statistically different from transcript levels seen in their wild-type siblings. Ubiquitin hydrolase activity was reduced approximately twofold in the HEXB-/- mice when compared to wild-type animals (Table 2). Although the absolute values of ubiquitin hydrolase activity were significantly higher in mouse brain than in human fibroblast homogenates, the degree of reduction was consistent between the two models. Western blots also showed reduced levels of the $\mathrm{UCH}-\mathrm{L} 1$ protein in the brain homogenates of the HEXB-/- mice as compared with their wild-type siblings (Table 2, quantification results and representative blot are shown on Supplementary Figure 2). Finally, we used a mass spectrometry-based approach to quantify the $\mathrm{UCH}-\mathrm{L} 1$ protein directly in pooled whole brain extracts. Pooled extracts of $\mathrm{HEXB}-/-$ and pooled extracts of $\mathrm{HEXB}+/+$ mice were separated by SDS-PAGE. Gel pieces containing the $\mathrm{UCH}-\mathrm{L} 1$ protein band as detected by Western blot were excised from gels, treated with trypsin and analyzed by LCMS/MS. Three independent experiments were performed. The relative abundance of the $\mathrm{UCH}-\mathrm{L} 1$ protein in two samples was defined as the square root of the Total Protein Spectral Intensity calculated as a sum of the total intensities of the MS spectra for all the assigned peptides (detected peptides and their intensity are shown on Supplementary Figure 3). We determined that $\mathrm{UCH}-\mathrm{L} 1$ protein levels were reduced approximately twofold in the brain extracts of the HEXB-/- animals when compared to the wild-type animals. Recent data indicated that in the brains of patients affected with Alzheimer's disease and Parkinson's disease, UCH-L1 undergoes post-translational modifications such as carbony- lation, methionine oxidation and cysteine oxidation, ${ }^{21}$ which significantly alter its activity. Our experiments also detected the presence of the UCH-L1 isoforms with three oxidized methionine residues, but the ratio between modified and nonmodified protein was similar for HEXB $+/+$ and HEXB-/ - animals (not shown).

E-64-Induced lysosomal storage results in reduced expression of UCH-L1. Although the above experiments confirmed downregulation of $\mathrm{UCH}-\mathrm{L} 1$ in cells and tissues with LSD, they could not define whether it was secondary to the lysosomal storage. Moreover UCH-L1 mRNA, protein and activity were also reduced in two fibroblast lines of Gaucher patients which do not typically have storage bodies under normal conditions, although it might mean that even Gaucher disease fibroblasts have a lysosomal pathology, even if subtle. Therefore, in order to determine whether reduced levels of $\mathrm{UCH}-\mathrm{L} 1 \mathrm{mRNA}$ and protein resulted from the lysosomal swelling, we induced this condition in normal cells by treating them with the cysteine protease inhibitor E-64 (epoxysuccinyl-leucylamido-(4-guanidino) butane). This compound enters cells by pinocytosis and inhibits lysosomal protein degradation, causing a significant increase in the number and volume of lysosomes as well as the formation of multivesicular dense bodies. ${ }^{22,23}$ In our experiments, 16-h incubation of normal control fibroblasts in the medium containing $0.5 \mathrm{mM}$ E-64 significantly increased lysosome number and size as visualized by immunohistochemical staining with anti-LAMP-2 antibodies (Figure 2a). The same organelles were also heavily stained with antiubiquitin antibodies showing the accumulation of ubiquitinated proteins in the lysosomes (Figure 2b).

We further treated normal fibroblasts with E-64 for $6-48 \mathrm{~h}$. Parallel plates of cells were used to prepare mRNA for 
RT-PCR studies as well as to measure UCH-L1 hydrolytic activity and the activities of lysosomal $\beta$ - $N$-acetyl hexosaminidase and caspase-3 (Figure 3a). RT-PCR studies showed significantly decreased UCH-L1 transcript levels following 6-h incubation with E-64, which correlated with the formation of lysosomal storage vacuoles (increase in lysosomal $\beta$ - $N$-acetyl hexosaminidase activity). A decrease in UCH-L1 activity

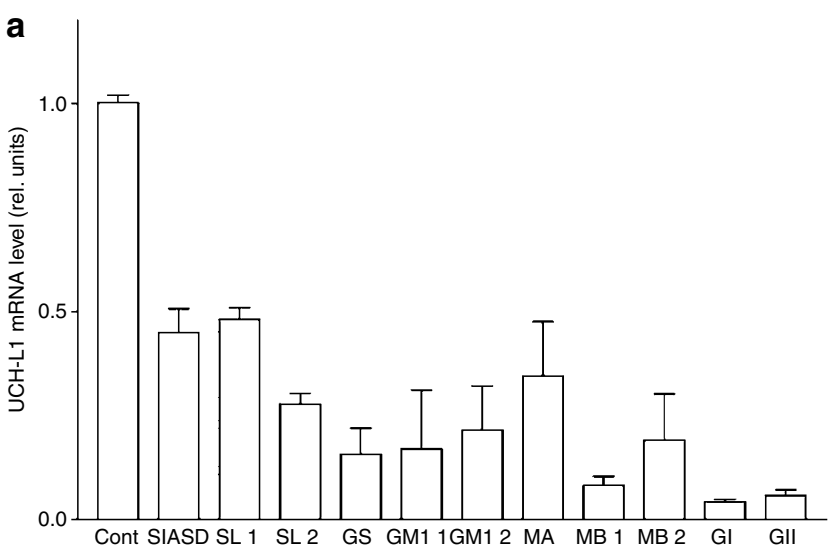

b
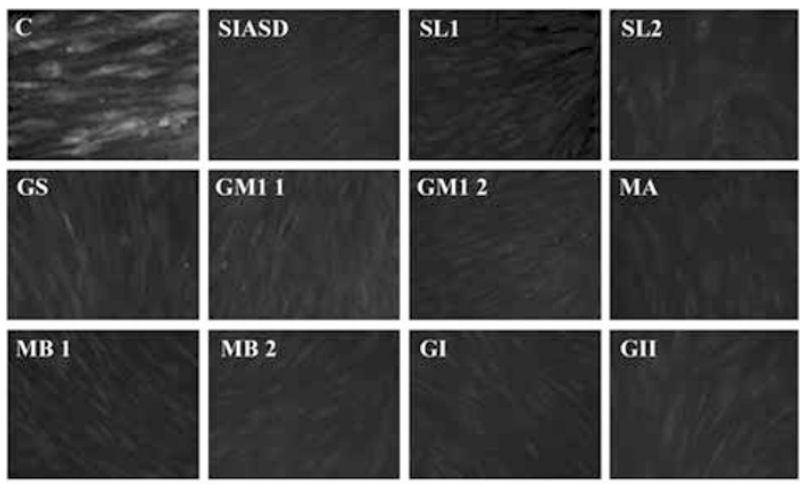

GII
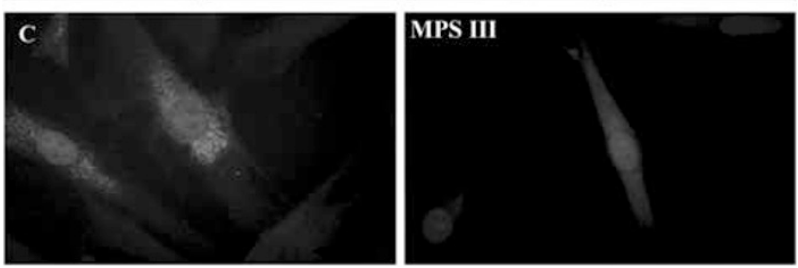

C

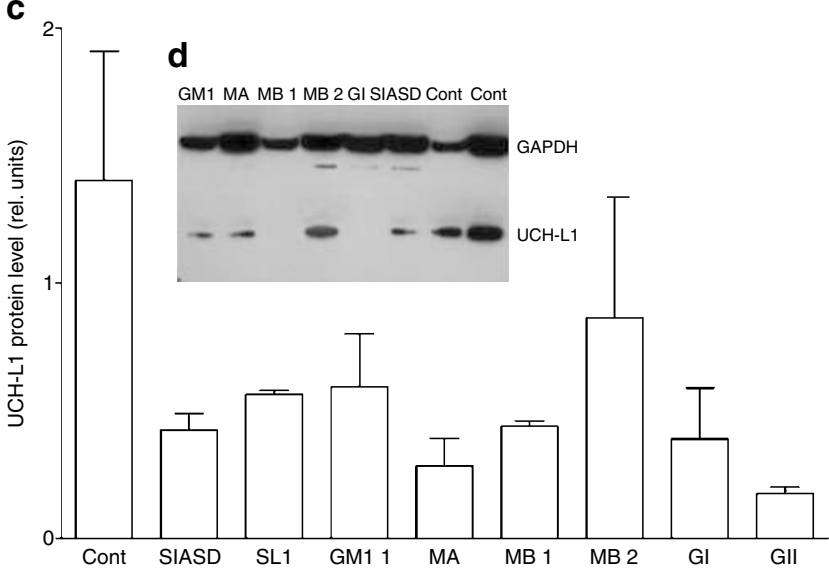

lagged $6 \mathrm{~h}$ after the decline in its mRNA level (Figure 3a). After treatment of the cells with E-64 for 24-h, immunofluorescent microscopy showed decreased levels of $\mathrm{UCH}-\mathrm{L} 1$ protein (Figure $3 \mathrm{~b}$ ). After 48-h treatment of cells with E-64, the $\mathrm{UCH}$ L1 mRNA level increased; however, by this time 50-60\% of cells had developed apoptosis as demonstrated by increased caspase-3 activity (Figure $3 a$ ), condensed nuclei (Figure $3 c$ ) and TUNEL staining (Figure 3d). We speculate that the increased mRNA level after $48 \mathrm{~h}$ may reflect the $\mathrm{UCH}-\mathrm{L} 1$ expression in the fraction of live cells, suggesting that the cells that did not die overexpress $\mathrm{UCH}-\mathrm{L} 1$. These experiments showed that the reduction in $\mathrm{UCH}-\mathrm{L} 1$ level and increase in apoptosis followed the onset of lysosomal storage although they could not establish a direct connection between these events.

Lysosomal storage induces formation of ubiquitinated protein conjugates, decreases the level of free ubiquitin, partially impairs proteasomal activity and increases apoptosis. As $\mathrm{UCH}-\mathrm{L} 1$ is the major cellular ubiquitin hydrolase maintaining the intracellular levels of free ubiquitin, ${ }^{24}$ we hypothesized that its suppression should impair the proteosomal ubiquitin-dependent protein degradation pathway, causing accumulation of ubiquitinated protein conjugates, cell deregulation and apoptosis, as was previously shown for human leukemic HL60 cells. ${ }^{25}$ Indeed immunofluorescent microscopy with a mouse monoclonal antiubiquitin antibody revealed that all cells from LSD patients showed a predominantly perinuclear punctate staining pattern consistent with mainly lysosomal localization of ubiquitinated proteins (Figure 4a). Colocalization of ubiquitinated aggregates with lysosomal markers LAMP-2 and LysoTracker Red (not shown) confirmed that the lysosomal dense bodies were heavily ubiquitinated. Western blots of total cell homogenates showed that the majority of cellular ubiquitin in LSD patient

Figure 1 Suppression of UCH-L1 in cultured fibroblasts obtained from the LSD patients. (a) UCH-L1 mRNA levels in the control fibroblasts (Cont, $n=5)$ and in the cells from the patients affected with SIASD (SIASD), sialidosis (SL 1 and SL 2),

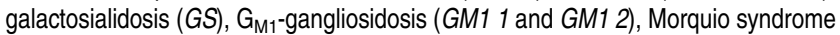
type $\mathrm{A}(M A)$ and $\mathrm{B}$ (MB 1 and $M B$ 2) and Gaucher disease types I (GI) and II (GII). The UCH-L1 mRNA was quantified by quantitative real-time PCR as described. The $\mathrm{UCH}-\mathrm{L} 1 \mathrm{mRNA}$ level is presented as a fraction of that in normal control cells (Cont) Values represent means \pm S.D. of three independent experiments. (b) Immunohistochemical detection of UCH-L1 in the control cells (c) and the cells obtained from the LSD patients. Plates of confluent cells were fixed, stained with a mouse monoclonal anti-UCH-L1 antibody, and Oregon Green 488-conjugated secondary antibodies. Slides were studied on a Zeiss LSM510 inverted confocal microscope. Magnification $\times 200$. Lower panels show high-resolution image (magnification $\times 1000$ ) of control normal fibroblasts and of mucopolysaccharidosis type III patient (MPS III) stained with anti-UCH-L1 antibody and counterstained with DAPI, which demonstrates that in both cases the protein is expressed in the cytosol. (c) Western blot of UCH-L1 in the control cells (c) and the cells obtained from the LSD patients. The cell homogenates ( $\sim 15 \mu \mathrm{g}$ of total proteins) were separated on a NuPAGE 4 $12 \%$ Bis-Tris gel (Invitrogen) and transferred to a PVDF membrane. The membrane was stained with Ponceau $S$ then cut horizontally between 50 and $37 \mathrm{kDa}$ markers. The upper part of membrane was incubated with anti-GAPDH antibodies and the lower part with anti-UCH-L1 antibodies. The UCH-L1 protein level is presented as a ratio of total intensities of $\mathrm{UCH}-\mathrm{L} 1$ and GAPDH immunoreactive bands. Inset shows a representative Western blot (d) 
Table 2 UCH-L1 cDNA, activity and protein levels in total brains of HEXB-/-, HEXB+/- and HEXB+/+ siblings of Sandhoff mice

\begin{tabular}{|c|c|c|c|c|c|c|c|c|c|c|c|c|}
\hline \multirow[t]{2}{*}{ Mice } & \multicolumn{4}{|c|}{ UCH activity ${ }^{a}$} & \multicolumn{4}{|c|}{ UCH-L1 mRNA } & \multicolumn{4}{|c|}{ UCH-L1 protein ${ }^{b}$} \\
\hline & Mean & s.d. & $n$ & $P$-value ${ }^{c}$ & Mean & s.d. & $n$ & $P$-value ${ }^{c}$ & Mean & s.d. & $n$ & $P$-value ${ }^{c}$ \\
\hline $\begin{array}{l}\text { HEXB+/+ } \\
\text { HEXB+/- } \\
\text { HEXB-/- }\end{array}$ & $\begin{array}{l}148.4 \\
131 \\
87.8\end{array}$ & $\begin{array}{l}28.4 \\
43.2 \\
39.6\end{array}$ & $\begin{array}{r}5 \\
10 \\
9\end{array}$ & $\begin{array}{l}0.43 \\
0.01\end{array}$ & $\begin{array}{l}1.0 \\
0.83 \\
0.53\end{array}$ & $\begin{array}{l}0.26 \\
0.49 \\
0.45\end{array}$ & $\begin{array}{r}6 \\
4 \\
10\end{array}$ & $\begin{array}{l}0.34 \\
0.02\end{array}$ & $\begin{array}{l}1.15 \\
N A^{d} \\
0.85\end{array}$ & 0.03 & 5 & 0.002 \\
\hline
\end{tabular}

${ }^{\mathrm{a}} \mathrm{UCH}$ activity is expressed in $\mathrm{nmol} / \mathrm{h} \mathrm{mg}$ of total protein. ${ }^{\mathrm{b}}$ Measured by western blot and expressed as a ratio of total intensities of $\mathrm{UCH}-\mathrm{L} 1$ and $\mathrm{GAPDH}$ immunoreactive bands. ${ }^{\mathrm{C}}$ Two-tailed. ${ }^{\mathrm{d}}$ Not measured.
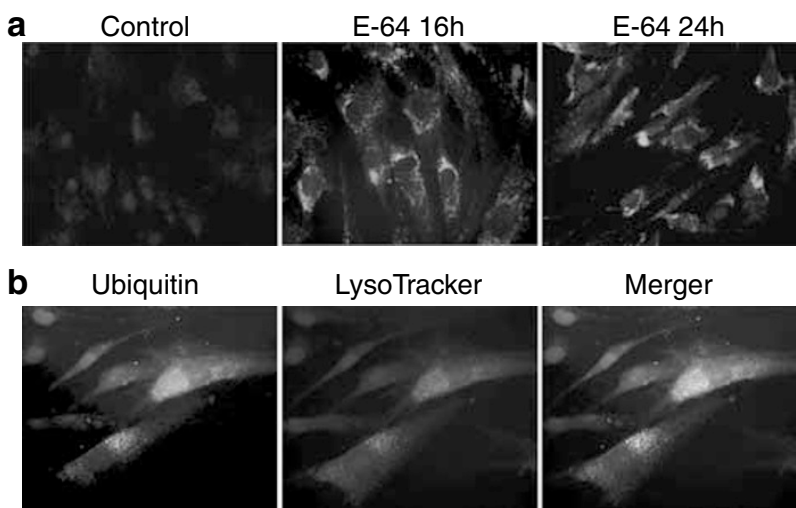

LysoTracker
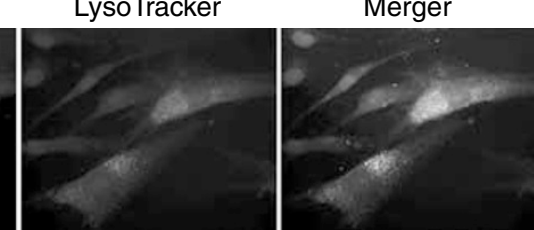

Figure 2 Ubiquitinated lysosomal storage bodies in cultured skin fibroblasts treated with E-64. (a) Lysosomal storage bodies in untreated normal fibroblasts (Control) or normal fibroblasts treated with $0.5 \mathrm{mM} \mathrm{E}-64$ for $16 \mathrm{~h}(\mathrm{E}-6416 \mathrm{~h}$ ) or $24 \mathrm{~h}$ (E-64 24h). The cells were fixed, stained with mouse monoclonal anti-human LAMP-2 antibodies, and counterstained with Oregon Green 488-conjugated secondary antibodies. Cell nuclei were visualized with DAPI. (b) Immunohistochemical localization of ubiquitinated proteins in the E-64-treated cells. Following incubation with $0.5 \mathrm{mM} \mathrm{E}-64$ for $24 \mathrm{~h}$, the cells were probed with LysoTracker Red, fixed, stained with mouse monoclonal antiubiquitin antibodies, and counterstained with Oregon Green 488-conjugated secondary antibodies. Panels show ubiquitinrelated green immunofluorescence (Ubiquitin), LysoTracker-related red fluorescence (LysoTracker) and merged images. Magnification $\times 600$ (a) or $\times 1000$ (b)

cells is associated with high molecular weight protein aggregates; in contrast, the amount of free monomeric ubiquitin is significantly reduced (Figure 4b). Chymotryptic and tryptic activity measured in the 26S and $20 S$ proteosomal fractions were also significantly reduced in the cells of LSD patients, in the E-64-treated control cells and in the brains of Sandhoff HEXB-/- mice (Figure 5). The proteosomal activity, however, was not affected in the cells treated with $0.5 \mathrm{mM} \mathrm{E}-64$ for $2 \mathrm{~h}$ (i.e. before the beginning of apoptosis) or when $1 \mathrm{mM} \mathrm{E-64}$ was added directly to the cell homogenates indicating that the inhibition of the proteosomal activity was not caused by a nonspecific action of E-64.

We observed cells with condensed nuclei (data not shown) as well as TUNEL-positive cells in all studied fibroblast lines from LSD patients (Figure 6). The fraction of apoptotic cells was variable, ranging from $\sim 5$ to $\sim 50 \%$ (nuclear condensation assay) and $\sim 4$ to $\sim 50 \%$ (TUNEL-positive cells). In contrast, control lines cultured under the same experimental conditions did not undergo apoptosis. Caspase-3 activity was detected in all LSD patient cell lines but not in control cells (data not shown).
We further studied E-64-induced apoptosis in normal skin fibroblasts transfected with an expression vector coding for $\mathrm{UCH}-\mathrm{L} 1$ containing a FLAG tag on the C-terminus (pCMVUCH-L1-FLAG). Separate experiments demonstrated that COS 7 cells transfected with pCMV-UCH-L1-FLAG expressed catalytically active UCH-L1 (not shown). At $24 \mathrm{~h}$ after transfection with either pCMV-UCH-L1-FLAG or with pCMVTag 4a (mock), the fibroblasts were treated with E-64 for $24 \mathrm{~h}$, and then fixed, stained with anti-FLAG peptide antibodies and assayed for apoptosis using a TUNEL kit. As shown on Figure 7, the FLAG-positive cells overexpressing UCH-L1 demonstrated significantly reduced rate of apoptosis under our experimental conditions. About $\sim 35 \%$ of the control cells were TUNEL-positive, whereas, only $\sim 7 \%$ of the FLAGpositive cells showed TUNEL staining (Figure 7).

In contrast, when we used siRNA to inhibit the expression of $\mathrm{UCH}-\mathrm{L} 1$ in normal control fibroblasts, we observed a remarkable increase of apoptosis both in the presence and in the absence of E-64. Our preliminary experiments showed that UCH-L1 siRNA 14311 almost completely inhibited synthesis of $\mathrm{UCH}-\mathrm{L} 1$ protein in about $70 \%$ of cells (Supplementary Figure 4A). On average, the UCH-L1 mRNA level measured by RT-PCR was reduced more then sevenfold (Supplementary Figure 4). Pronounced reduction of UCH-L1 protein was also detected by the Western blot (Supplementary Figure 4). When the cells were treated with similar concentration of UCH-L1 siRNA 14311 for $48 \mathrm{~h}$, the fraction of TUNEL-positive cells increased from $3-5 \%$ to $\sim 60 \%$ (Figure $8 \mathrm{a}$ ). In the presence of E-64, the fraction of TUNEL-positive cells increased from $24 \%$ (mock-transfected cells) to 53\% (siRNA-transfected cells) (Figure $8 \mathrm{c}$ ). Similar results were obtained after staining the cells with a sulforhodamine multicaspase activity kit, which detects active caspases 1-9 in the live cells. Only $1-5 \%$ of the mock-transfected cells showed positive staining in the absence of E-64, while $25 \%$ showed positive staining in the presence of E-64 (Figure 8b). In contrast, $\sim 54 \%$ of siRNA-transfected cells were caspasepositive both in the presence and in the absence of E-64 (Figure 4c). Interestingly, double staining of the cells with pancaspase substrate and with anti-UCH-L1 antibodies or with anti-UCH-L1 antibodies and TUNEL showed that apoptosis was triggered exclusively in the cells depleted of $\mathrm{UCH}-\mathrm{L} 1$ protein, suggesting that the inhibition of the $\mathrm{UCH}-\mathrm{L} 1$ expression alone was sufficient to cause the cell death in cultured skin fibroblasts (Figure $8 b$ and $c$ ).

In order to address the molecular mechanism by which the $\mathrm{UCH}-\mathrm{L} 1$ deficiency triggers apoptotic pathways, we measured the level of pro- and antiapoptotic proteins in the cells treated 
with the UCH-L1 siRNA for 12, 24 and $48 \mathrm{~h}$. After harvesting the cells, nuclear, mitochondrial and cytosolic fractions were prepared by differential centrifugation. The subcellular fractions and the total homogenates were analyzed by Western blots using antibodies directed against several known pro-

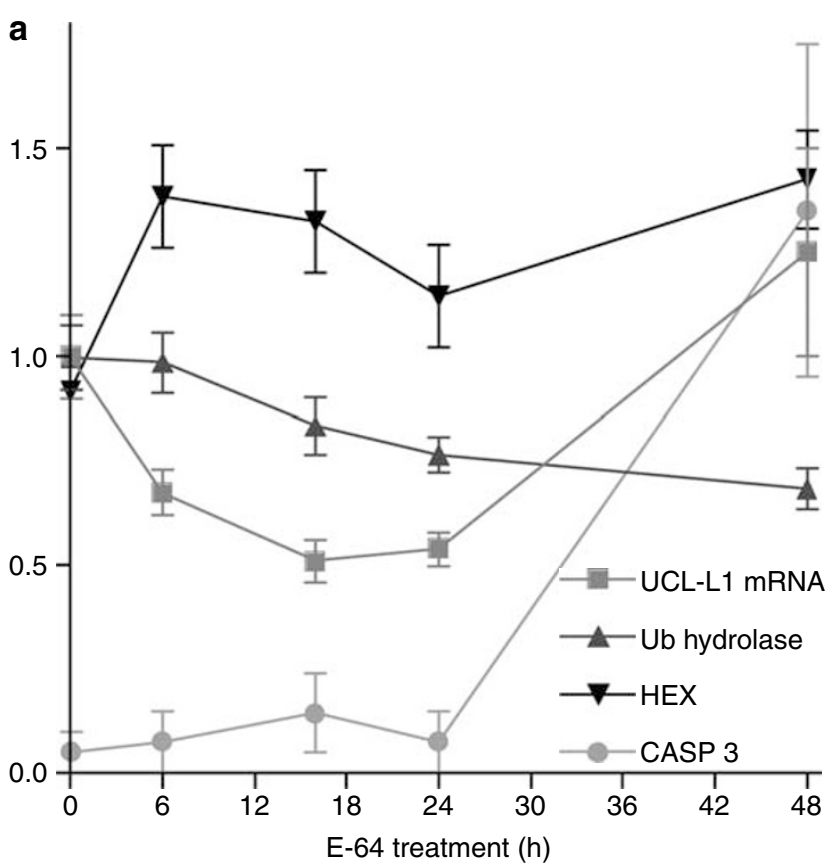

b

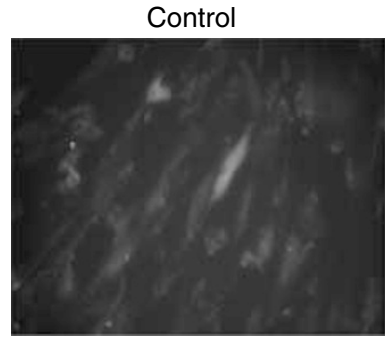

C

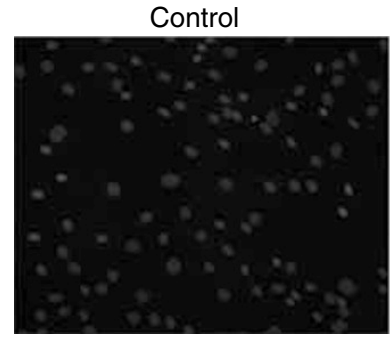

d

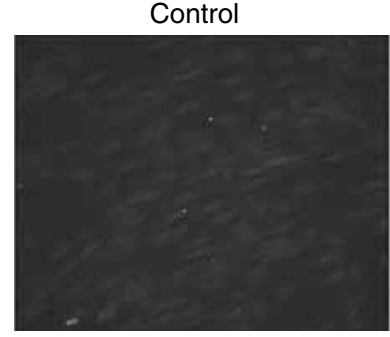

E-64 24h

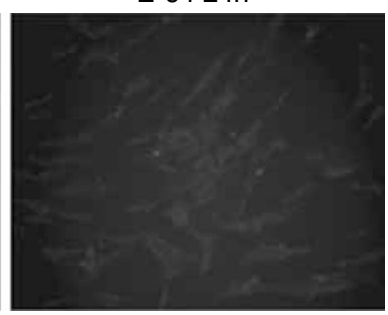

E-64 48h

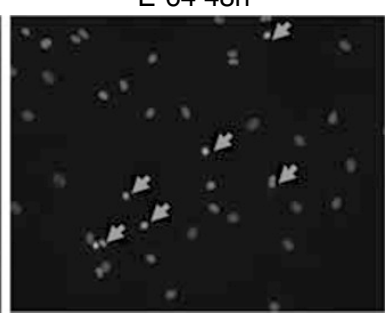

E-64 48h

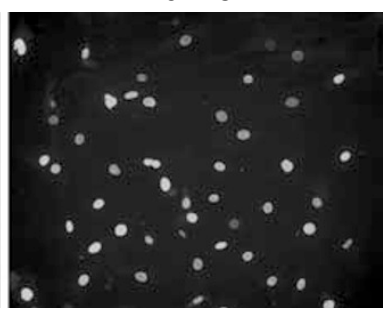

and antiapoptotic gene products. The expression of proapoptotic proteins Bim and Bax was significantly increased between 12 and $48 \mathrm{~h}$ after treatment of the cells with siRNA (Figure 9). The same cells showed a twofold increase in cytosolic cytochrome $c$ level, consistent with its translocation

a
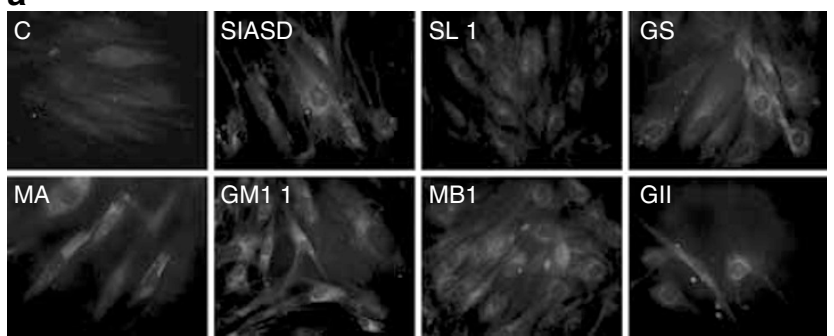

b $\underline{M r(k D a)}$

MB1 MB2 GM1 MA SL SIASD GII C1 C2

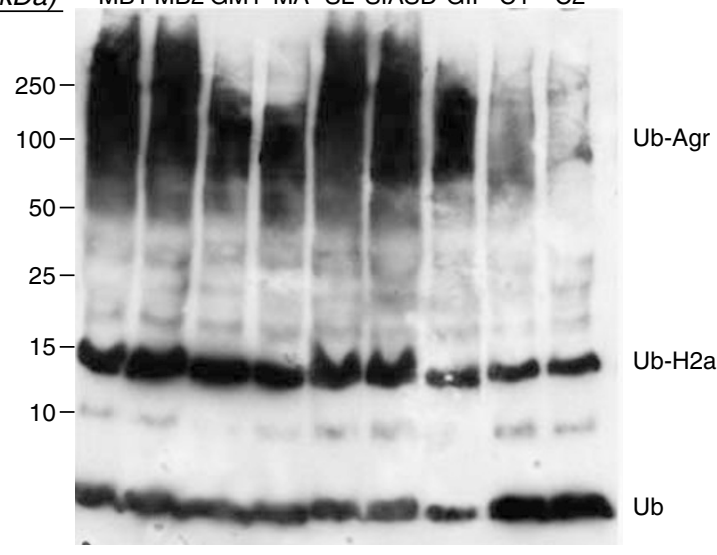

Figure 4 Detection of ubiquinated proteins in the cells with lysosomal storage. (a) Immunohistochemical localization of ubiquitinated proteins in the control fibroblasts $(C)$ and in the cells of patients affected with SIASD (SIASD), sialidosis $(S L$ 1), galactosialidosis $(G S)$, Morquio syndrome type $A(M A)$ and $B(M B 1)$ and Gaucher disease type II (GII). Cells were stained with mouse monoclonal antiubiquitin antibodies, and counterstained with Oregon Green 488-conjugated secondary antibodies. (b) Western blots of lysates of control cells (C1 and C2) and the cells obtained from the patients affected with Morquio syndrome type $A(M A)$ and $B$ (MB1 and MB2), $G_{M 1}$-gangliosidosis (GM1), sialidosis (SL), SIASD (SIASD) and Gaucher disease type II (GII) Each lane contains $40 \mu \mathrm{g}$ of total protein. Immunoblotting was performed with antiubiquitin rabbit polyclonal antibodies. The position of ubiquitinated protein aggregates (Ub-Agr), ubiquitinated histone $\mathrm{H} 2 \mathrm{a}$ $(\mathrm{Ub}-\mathrm{H} 2 \mathrm{~A})$ and free ubiquitin $(\mathrm{Ub})$ are shown on the right side of blot

Figure 3 Development of lysosomal storage, UCH-L1 deficiency and apoptosis in the cultured skin fibroblasts treated with E-64. (a) Cultured skin fibroblasts from normal controls were incubated with or without $0.5 \mathrm{mM} E-64$. The cells were harvested at the indicated time intervals and assayed for UCH-L1 mRNA level by RT-PCR (UCH-L1 mRNA), ubiquitin hydrolase activity (Ub hydrolase), lysosomal $\beta$ hexosaminidase activity (HEX) and caspase-3 activity (CASP 3) as described. Values represent means \pm S.D. of three independent experiments. (b) Immunohistochemical localization of UCH-L1 in control cells and cells treated with E-64 for $48 \mathrm{~h}$. The cells were stained with mouse monoclonal anti-UCH-L1 antibodies, and counterstained with Oregon Green 488-conjugated secondary antibodies. (c) Epifluorescent microscopy of DAPI-stained control cells and those treated with E-64 for $48 \mathrm{~h}$. Arrowheads show condensed nuclei in the apoptotic cells. (d) Epifluorescent microscopy of TUNEL-stained control cells and those treated with E-64 for $48 \mathrm{~h}$. Slides were studied on the Nikon Eclipse E6000 direct epifluorescence microscope. Magnification $\times 400$ 
from the mitochondria to the cytoplasm through the Baxinduced pores in the mitochondrial membrane. The level of prosurvival protein $\mathrm{Bcl}-2$ was not increased at the statistically significant level.

\section{Discussion}

The ubiquitin pathway is responsible for the proteasomemediated turnover of short-lived regulatory proteins as well as

a
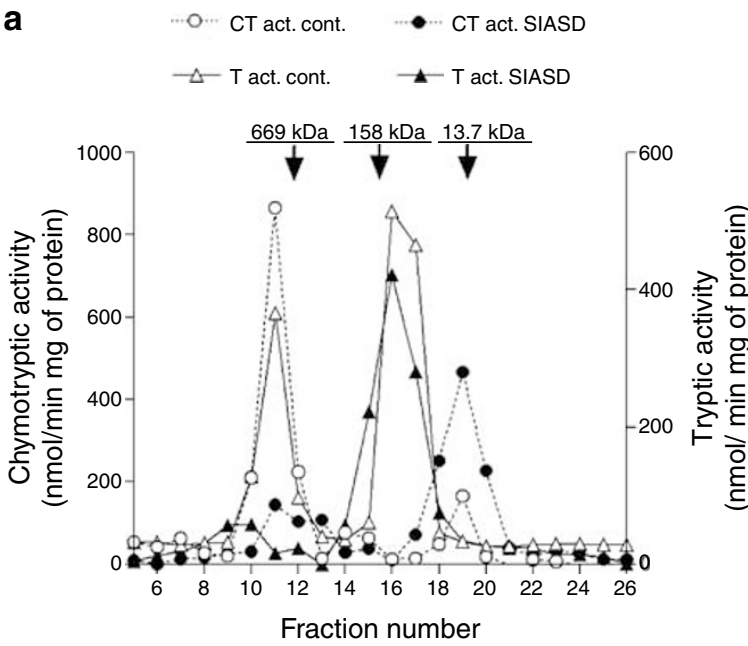

b

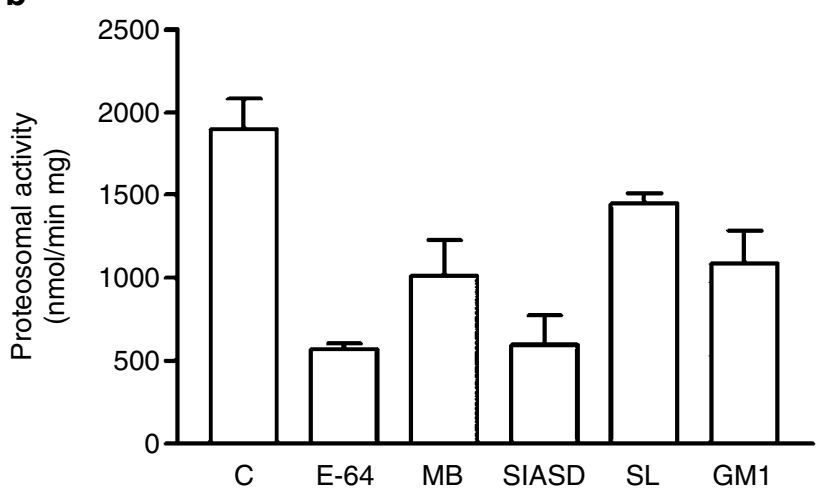

C

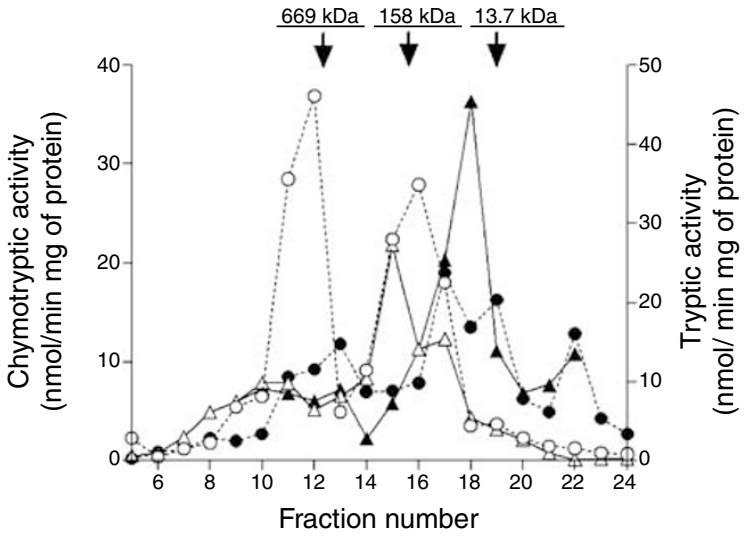

for the degradation of misfolded, unassembled or damaged proteins that could be potentially dangerous for the cell (reviewed by Varshavsky ${ }^{26}$ ). Ligation of the activated ubiquitin to substrate proteins by ubiquitin protein ligases, targets them to proteasomes or lysosomes where proteolysis occurs. Previously, protein aggregation in the cells transiently transfected with polyglutamine repeat-containing proteins was shown to directly cause near-complete inhibition of the ubiquitin-proteasome system. ${ }^{27}$ Our studies demonstrate that impairment of the ubiquitin protein degradation pathway also takes place in the cells from LSD patients in which the lysosomal protein degradation system is overwhelmed by undegraded macromolecules.

We have shown that the expression of the most abundant cellular ubiquitin $\mathrm{C}$-terminal hydrolase, $\mathrm{UCH}-\mathrm{L} 1$, is inhibited in cells from LSD patients including those affected with sialidosis, SIASD, galactosialidosis, $\mathrm{G}_{\mathrm{M} 1}$-gangliosidosis, Morquio disease type $A$ and $B$, and Gaucher disease, as well as in
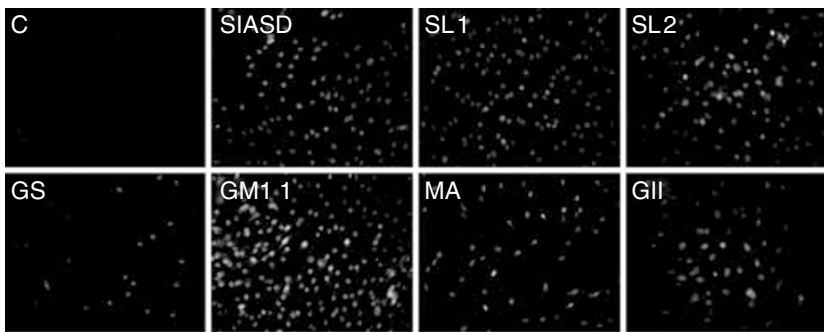

Figure 6 Development of apoptosis in cultured skin fibroblasts from LSD patients. Normal control cells $(C)$ and the cells of patients affected with SIASD (SIASD), sialidosis (SL 1; SL 2), galactosialidosis (GS), GM1-gangliosidosis (GM1 1), Morquio syndrome type $A(M A)$ and Gaucher disease type II (GI) were grown to confluent layers on glass slides and incubated for $48 \mathrm{~h}$ in MEM supplemented with $10 \%$ fetal calf serum. Cells were washed twice with ice-cold PBS and fixed with $3.8 \%$ paraformaldehyde in PBS for $30 \mathrm{~min}$. Cells were stained for DNA fragmentation using a TUNEL (Fluorescein in situ Cell Death Detection) kit from Roche. Slides were studied on the Nikon Eclipse E6000 direct epifluorescence microscope. Magnification $\times 400$. While control cells were completely TUNELnegative, cells from the patients affected with LSD contained the following fractions of apoptotic cells: 50\% (GM1 1); 20-25\% (SIASD, SL 1, SL 2); 12-15\% (MA, GII) and $4 \%(G S)$

Figure 5 Decrease of proteosomal activity in the cultured skin fibroblasts from LSD patients (a, b) and in brain tissues of Sandhoff mice (c). (a) FPLC gel-filtration of the extracts of normal control skin fibroblasts and of cells from SIASD patients on a Superose 6 column. Chymotryptic and tryptic proteolytic activities in the fractions 10-12 corresponding to the expected elution volume of $26 \mathrm{~S}$ and $20 \mathrm{~S}$ proteasomes are significantly reduced. Positions of the elution of the Mr standards: thyroglobulin (669 $\mathrm{kDa})$, aldolase (158 kDa) and ribonuclease $\mathrm{A}(13.7 \mathrm{kDa}$ ) are shown by arrows. (b) Proteosomal activity in the normal control fibroblasts $(C)$, in the cells from the patients affected with Morquio syndrome type $\mathrm{B}(M B)$, SIASD $(S I A S D)$, sialidosis (SL), $\mathrm{G}_{\mathrm{M1}}$-gangliosidosis (GM1) and in control cells treated for $24 \mathrm{~h}$ with $0.5 \mathrm{mM}$ cysteine protease inhibitor E-64 (E-64). The cells extracts were analyzed by gelfiltration as described. Data show combined chymotryptic and tryptic activity measured in the pooled fractions 10-12 collected after FPLC gel-filtration of cell extracts on a Superose 6 column. Values represent means \pm S.D. of two independent experiments. (c) FPLC gel-filtration of the pooled brain extracts of HEXB-I - and HEXB + I + siblings of Sandhoff mice on a Superose 6 column. Chymotryptic proteolytic activity is significantly reduced in the fractions 10-12 corresponding to the expected elution volume of $26 \mathrm{~S}$ and $20 \mathrm{~S}$ proteasomes 

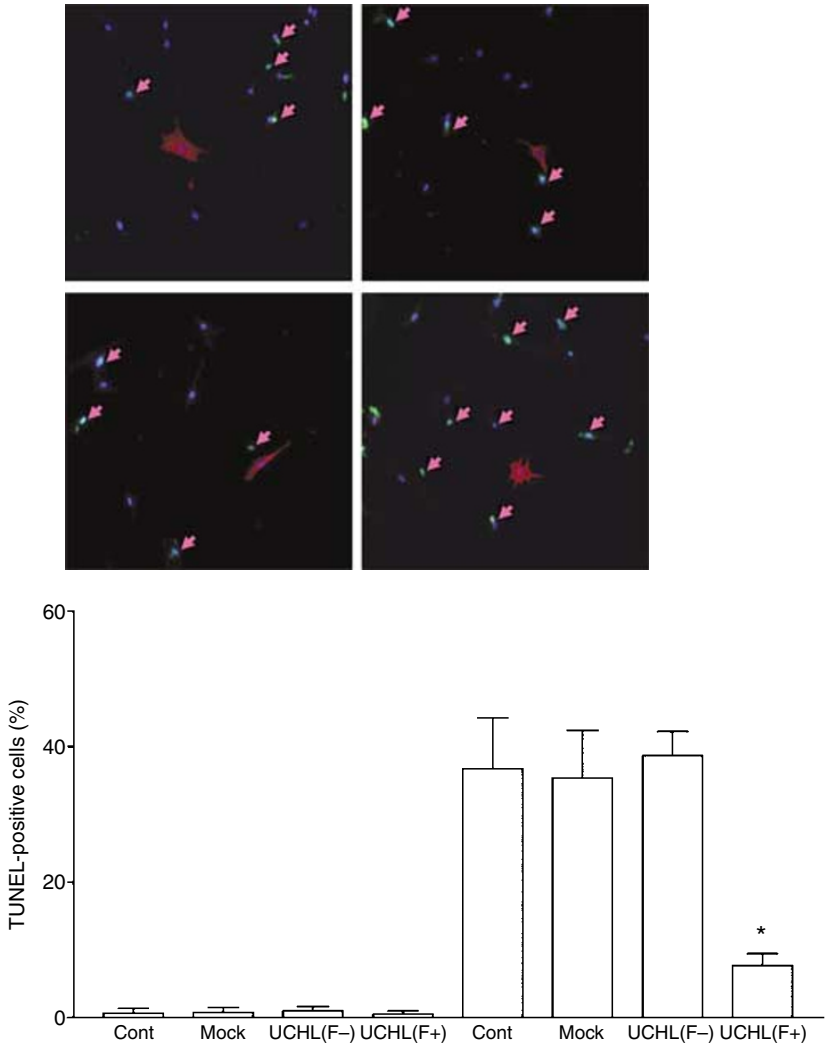

Figure 7 Suppression of the E-64-induced apoptosis in cultured skin fibroblasts. Normal control fibroblasts (Cont) and the fibroblasts transfected with the pCMV-UCH-L1-FLAG plasmid (UCHL) or with the pCMV-Tag 4a plasmid (Mock) were incubated in the presence of $0.5 \mathrm{mM} \mathrm{E}-64$ for $24 \mathrm{~h}$. Then the cells were fixed, and stained for the expression of the UCH-L1-FLAG fusion protein with anti-FLAG peptide antibodies, and for DNA fragmentation using TUNEL assay. Nuclei were stained with DAPI. A cumulative number of apoptotic deaths per 100 cells was counted basing on TUNEL staining using epifluorescent microscopy. For the pCMVUCH-L1-FLAG-trasfected cells apoptotic deaths were counted separately for the FLAG-negative $(F-)$ and the FLAG-positive cells $(F+)$. Values represent means \pm S.D. of triplicate experiments; from 200 to 300 cells were counted for each condition for each experiment. ${ }^{*} P<0.001$ as compared to nontransfected cells, mock-transfected cells or FLAG-negative cells. Inset: Epifluorescent microscopy of randomly selected representatives of the pCMV-UCH-L1-FLAGtransfected cells treated with E-64 for $24 \mathrm{~h}$. Pseudo-colors show DAPI staining (blue) TUNEL staining (green) and anti-FLAG staining (red). Arrowheads show apoptotic TUNEL-positive cells. Slides were studied using a Nikon Eclipse E6000 direct epifluorescence microscope. Magnification $\times 400$

normal fibroblasts in which the accumulation of lysosomal storage materials was induced by the cysteine protease inhibitor E-64. UCH-L1 was also reduced in the brains of Sandhoff mice that showed neuronal lysosomal storage and accumulation. $\mathrm{UCH}-\mathrm{L} 1$ is especially abundant in neurons and neuroendocrine cells where it represents $1-2 \%$ of total soluble protein, ${ }^{28}$ but is also expressed in skin fibroblasts. ${ }^{29}$ Previous studies have shown that the UCH-L1 deficiency is involved in the pathogenesis of several neurodegenerative disorders. In mice, mutation of the $\mathrm{UCH}-\mathrm{L} 1$ gene results in gracile axonal dystrophy (GAD), a disorder characterized by axonal degeneration of the gracile tract: the affected animals display sensory ataxia followed by posterior paralysis and death. ${ }^{30}$ Pathological examination of the GAD mice revealed ubiqui- a

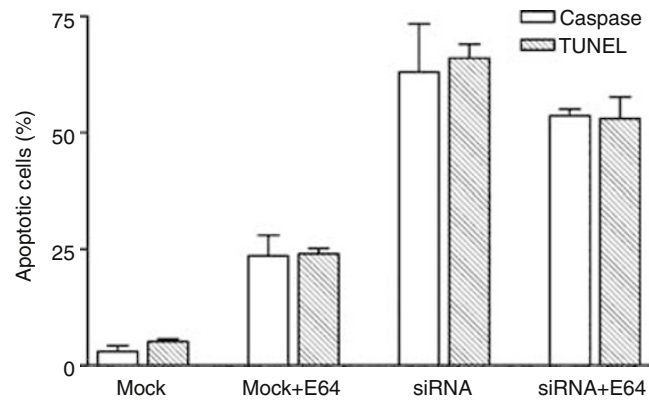

b

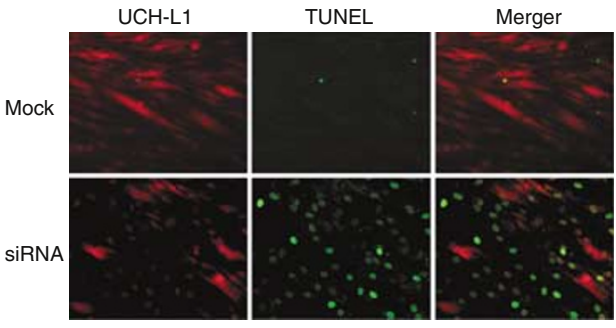

C

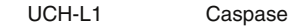

Mock

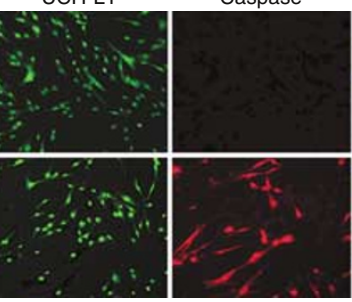

DAPI
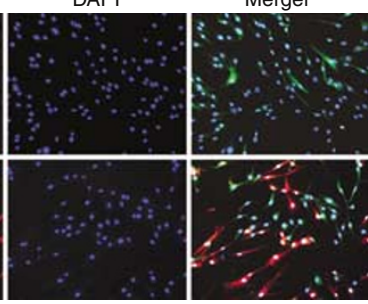

Figure 8 Induction of apoptosis by the siRNA-induced inhibition of UCH-L1 expression. Fibroblasts transfected with the UCH-L1 siRNA (siRNA) and mocktransfected cells (Mock) were incubated in the absence and the presence of $0.5 \mathrm{mM}$ $\mathrm{E}-64$ for $24 \mathrm{~h}$. Then the cells were fixed, and stained for apoptosis using TUNEL kit or sulforhodamine multicaspase activity kit. A cumulative number of apoptotic deaths per 100 cells was counted basing on TUNEL or multicaspase activity staining using epifluorescent microscopy (a). Values represent means \pm S.D. of triplicate experiments. Between 450 and 800 cells were counted for each condition in each experiment. In a separate experiment the cells transfected with UCHL-1 siRNA were stained for TUNEL (b) or multicaspase (c) activity and counterstained for the UCH$\mathrm{L} 1$ protein as described above. Pseudo-colors show multicaspase activity staining (red), TUNEL staining (green), DAPI staining (blue) and anti-UCH-L1 staining (red in b and green in c)

tinated inclusion bodies, and dot-like deposits of proteasome immunoreactivity, indicating storage of proteosomal substrates; similar observations were made in transgenic mice in which the double-knockout of the UCH-L1 and UCH-L3 genes resulted in posterior paralysis, dystrophic neurons and increased neuronal death mostly due to oxidative damage. ${ }^{30-32}$ In Drosophila, genetic screens have shown that an $\mathrm{UCH}-\mathrm{L} 1$ homolog can enhance ataxia resulting from ablation of ataxin1 function. ${ }^{33}$ In humans, a missense mutation (I93M) in $\mathrm{UCH}$ $\mathrm{L} 1$ has been linked to the rare form of Parkinson's disease. ${ }^{19}$ Further studies attributed the pathogenicity of this mutation to the increased Ub-ligase activity, while the S18Y polymorphism in the UCH-L1 gene, which results in the reduced ligase activity was linked to a decreased susceptibility to Parkinson's disease. ${ }^{34}$

Ubiquitinated protein aggregates have been observed in tissues of mice and humans affected with $\operatorname{LSD}^{1-4}$ although 
a

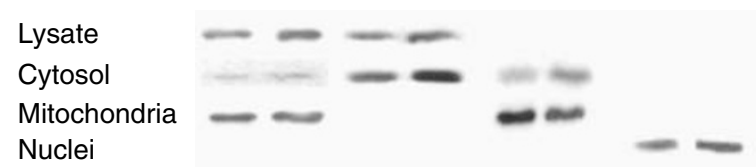

Nuclei

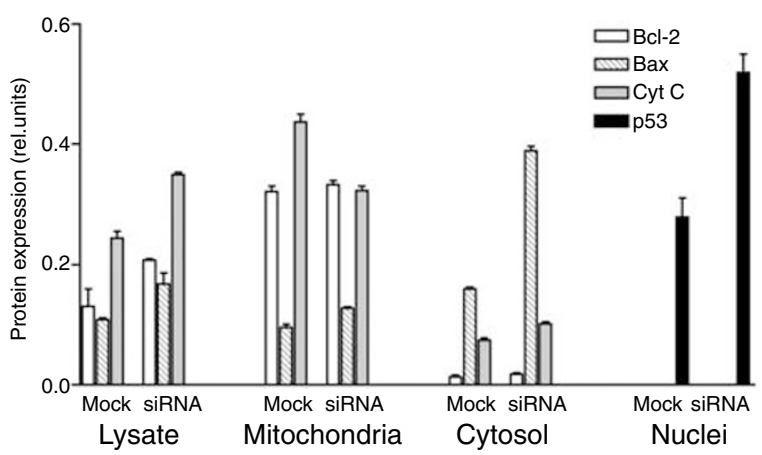

b
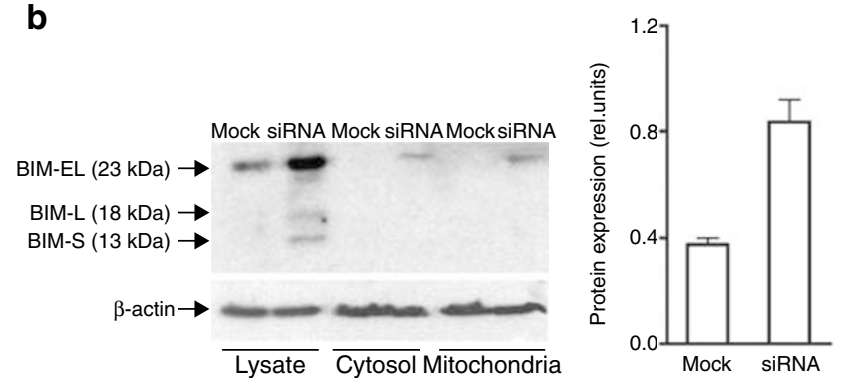

Figure 9 Expression of pro- and antiapoptotic proteins in the cultured skin fibroblasts treated with the UCH-L1 siRNA. Cultured human skin fibroblasts transfected for $48 \mathrm{~h}$ with the UCH-L1 siRNA (siRNA) and mock-transfected cells (Mock) were harvested and fractionated on nuclei, mitochondrial fraction and cytosol by the differential centrifugation. $20 \mu \mathrm{g}$ of total protein from cytosol, mitochondrial fractions and from the total homogenates and $30 \mu \mathrm{g}$ of total protein from nuclear fractions were analyzed by Western blots using antibodies against $\mathrm{p} 53$, $\mathrm{Bax}, \mathrm{Bcl}-2$, cytochrome $c$ and $\beta$-actin (a) or antibodies against Bim and $\beta$-actin (b). Panels show representative images from three independent experiments and relative intensities of immuno-reactive bands normalized for the intensities of $\beta$-actin immuno-reactive bands on the same lanes. Values represent means \pm S.D. of three independent experiments

Zhan et al. ${ }^{1}$ viewed it as an nonspecific epiphenomenon rather than a mechanism of biological significance. Our data suggest that intracellular storage of the ubiquitinated aggregates seen in the patients affected with LSD is related to the secondary UCH-L1 deficiency, which also results in lower levels of free monomeric ubiquitin, significantly decreased proteosomal activity and increased apoptosis.

Recent studies ${ }^{24}$ have shown that $\mathrm{UCH}-\mathrm{L} 1$ plays an important role in the maintenance of the intracellular monoubiquitin $(\mathrm{mUb})$ level either by generating mUb through the hydrolysis of mono-ubiquitinated proteins intended for lysosomal degradation or/and by binding mUb and thus preventing its intralysosomal degradation. Under conditions of lysosomal storage, the degradation of $\mathrm{Ub}$ in the lysosome is presumably impaired, as suggested by the observed accumulation of ubiquitinated material in lysosomal dense bodies. It is tempting to speculate that downregulation of $\mathrm{UCH}-\mathrm{L} 1$ can be a part of the feedback mechanism to avoid a potential increase in mUb levels in the cytoplasm. However, reduction of UCH-L1 also suppresses deubiquitination of monoubiquitinated proteins before their degradation within the endosomal-lysosomal pathway and may cause an opposite effect: reduction of the mUb concentration in the cell below the critical level necessary to maintain the proteosomal activity. A recent paper by Ardley et al. $^{35}$ describes an increased level of aggresomes after overexpression of a $\mathrm{UCH}-\mathrm{L} 1$ variant bearing a 193M mutation that has reduced hydrolase activity in two siblings with Parkinson disease. ${ }^{19}$ This result is reflective of the reduced $\mathrm{UCH}-\mathrm{L} 1$ protein and hydrolase activity accompanying proteasomal inhibition and ubiquitin aggregate formation in our study.

Previous studies have shown that ubiquitination is one of the major mechanisms for the regulation of key proteins of the cell apoptotic machinery, such as p53 and the molecules of Bcl-2 family. For example Ub-dependent degradation of proapoptotic Bcl-2 family members Bid, Bax and Bak has been reported to promote cell survival (reviewed by Yang and $\mathrm{Yu}^{36}$ ). Moreover, recent studies on GAD and UCH-L3 knockout mice suggest that through regulation of $\mathrm{mUb}$ level, $\mathrm{UCH}$ L1 plays a role in balancing the expression of pro- and antiapoptotic proteins. ${ }^{24,37}$ The majority of tumors and cancer cell lines contain significantly upregulated $\mathrm{UCH}-\mathrm{L} 1$ (see for example Yamazaki et al. ${ }^{38}$ ). Bonin et al. ${ }^{39}$ found that prosurvival protein BDNF was importantly downregulated in whole mouse brains of young GAD mice lacking UCH-L1. In contrast, Harada et al. ${ }^{40}$ showed that the levels of antiapoptotic proteins $\mathrm{Bcl}-2$, XIAP and BDNF were increased in retinal cells of GAD mice reducing apoptosis. All these data suggest that the molecular responses for UCH-L1 deficiency are celltype and tissue-type specific and can result in both increased and decreased apoptosis.

In this study, we showed that transient transfection with a UCH-L1 expression plasmid significantly reduced apoptosis in cultured fibroblasts treated with the lysosomal cysteine protease inhibitor E-64, whereas siRNA-induced inhibition of $\mathrm{UCH}-\mathrm{L} 1$ expression caused apoptosis both in the presence and in the absence of E-64. Almost $100 \%$ of the siRNAtransfected cells were TUNEL-positive and showed the activated caspase cascade. The same cells also showed the presence of cytochrome $c$ in the cytosol, and significantly induced levels of protoapoptotic proteins Bax and p53. The level of prosurvival Bcl-2 was slightly induced, but less than the level of Bax. The highest induction was observed for proapoptotic BH3-only protein, Bim. The 23-kDa (extra large) form of this protein was increased more than twofold in the total lysate and appeared both in the cytosol and in the mitochondrial fraction. These data are consistent with the execution phase of apoptosis involving release of Bim from the cytoskeleton, its translocation to the mitochondria and interaction with $\mathrm{Bcl}-2$. This relieves Bax from $\mathrm{Bcl}-2$ bound complexes and causes translocation of Bax to the mitochondrial membrane, release of cytochrome $c$ to the cytoplasm and activation of the caspase cascade.

Although more experiments are needed to verify if the observed events occur in cell types other than cultured fibroblasts such as neurons, chondrocytes or hepatocytes specifically affected in LSD, we believe that our results 
provide initial insight into the complexity of the cellular response to lysosomal storage.

\section{Materials and Methods}

Cell culture. Human skin fibroblasts from patients affected with LSD: galactosialidosis (GM05076), $\mathrm{G}_{\mathrm{M1}}$-gangliosidosis (GM05653, GM05335), Morquio syndrome types A (GM00958) and B (GM01602, GM03251), sialidosis (GM01718A FP2601), Gaucher disease types I and II (GM00852, GM00372), and sialic acid storage disease (FP0421), as well as from normal controls (FN0065, FN0075 FN0996, FN0221, FN0342), were obtained from the NIGMS Human Genetic Mutant Cell Repository and from the Ste-Justine Hospital cell repository. Cells were cultured in MEM supplemented with $10 \%$ fetal calf serum.

RNA extraction and array studies. Total RNA was isolated from cells using Trizol reagent (Invitrogen) according to the manufacturer's instructions. RNA quantity and quality was analyzed spectrophotometrically and by the agaroseformaldehyde gel electrophoresis. Probes for the microarray analysis were prepared using $20 \mu \mathrm{g}$ of total RNA and were hybridized to Affymetrix HG-U95Av2 Gene Chips (Affymetrix, Santa Clara, CA, USA). The hybridized arrays were scanned and raw data extracted using the Microarray Analysis Suite 5.0 (MAS5, Affymetrix, Santa Clara, CA, USA). LSD cell line expression profiles were compared individually to profiles obtained from the three control lines using the intensities of individual probe pairs to obtain a statistical estimate of the significance of changes in gene expression. For the purposes of this study, genes whose expression levels differed in all nine comparisons were considered to be differentially expressed in the LSD patient-derived cell lines. The microarray data will be made available online through the NCBI Gene Expression Omnibus (www.ncbi.nlm.nih.gov/geo/).

Analysis of mRNA expression by real-time PCR. Total RNA was extracted and reverse transcribed as described above. PCR amplification was performed on a SmartCycler (Cepheid, Sunnyvale, CA, USA) using the SYBR Green PCR kit (Qiagen, Mississauga, ON, USA). The primer pairs, annealing temperatures, number of PCR cycles, and RNA amounts are shown in Supplementary Table I, which also shows the predicted sizes of the resulting PCR products. As a positive control for real-time PCR, we used mRNA coding for ribosomal subunit 18S (Ambion, Austin, TX, USA).

Confocal immunofluorescence microscopy. Skin fibroblasts of normal controls and of patients affected with LSD were treated for $1 \mathrm{~h}$ with $75 \mathrm{nM}$ LysoTracker Red DND-99 dye (Molecular Probes, Eugene, OR, USA), washed twice with ice-cold PBS and fixed with 3.8\% paraformaldehyde in PBS for $30 \mathrm{~min}$. Cells were permeabilized by $0.5 \%$ Triton X-100, blocked with $10 \%$ goat serum in PBS for $1 \mathrm{~h}$, stained with monoclonal anti-UCH-L1 antibodies $(1: 30)$, or monoclonal antiubiquitin antibodies $(1: 250)$ both from Novocastra (Newcastle, UK) and counterstained with Oregon Green 488-conjugated anti-mouse IgG antibodies (Molecular Probes, Eugene, OR, USA). Alternatively cells were double stained with FITC-labeled monoclonal anti-UCH-L1 antibodies, or monoclonal antiubiquitin antibodies and Texas Red-labeled monoclonal antibodies against LAMP-2 (Washington Biotechnology Inc., Baltimore, MD, USA). Slides were examined on a Zeiss LSM510 inverted confocal microscope (Carl Zeiss Inc., Thornwood).

Enzyme assays. Ubiquitin hydrolase activity was assayed using AMC-ubiquitin substrate as described. ${ }^{34}$ Briefly, $10 \mu \mathrm{l}$ of the cell or tissue homogenate $(\sim 1 \mu \mathrm{g}$ of protein) was added to $0.2 \mathrm{ml}$ of a $50 \mathrm{mM}$ Tris- $\mathrm{HCl}$ buffer ( $\mathrm{pH} \mathrm{7.6)}$, containing $0.5 \mathrm{mM}$ EDTA, $5 \mathrm{mM}$ DTT and $0.5 \mathrm{mM}$ AMC-ubiquitin. Reaction was monitored $\left(\lambda_{\mathrm{ex}}=380 \mathrm{~nm}, \lambda_{\mathrm{em}}=460 \mathrm{~nm}\right)$ at $25^{\circ} \mathrm{C}$ using a Shimadzu RF-5301 fluorescence spectrophotometer equipped with a microcuvette holder. Caspase-3 activity was measured using fluorogenic caspase-3 substrate II, Ac-DEVD-AMC and caspase-3 inhibitor I, Ac-DEVD-CHO, both from Calbiochem (Darmstadt, Germany). Briefly $20 \mu$ of the cell lysate ( $\sim 2 \mu \mathrm{g}$ of protein) was added to $500 \mu$ l of $100 \mathrm{mM}$ HEPES buffer (pH 6.8), containing 10\% sucrose, $0.1 \%$ CHAPS and $50 \mu \mathrm{M}$ Ac-DEVD-AMC or $50 \mu \mathrm{M}$ Ac-DEVD-AMC and $150 \mu \mathrm{M}$ Ac-DEVD-CHO. After 30 min incubation at $37^{\circ} \mathrm{C}$ the reaction was stopped by adding $1.5 \mathrm{ml}$ of $0.1 \mathrm{M}$ glycine buffer $(\mathrm{pH} 10.5)$ and the concentration of the AMC fluorochrome measured as above. Caspase-3 activity was determined from the difference of the reaction rates measured with and without the caspase inhibitor Ac-DEVD-CHO. Lysosomal enzymes $\beta$ hexosaminidase and $\beta$-galactosidase were assayed using the corresponding fluorogenic 4-methylumbelliferyl (Muf)-glycoside derivatives as substrates. ${ }^{41}$
Detection of ubiquitinated proteins by Western blotting. Cultured cells from LSD patients, and normal controls as well as control cells treated with $0.5 \mathrm{mM} \mathrm{E}-64$ for $24-48 \mathrm{~h}$ were harvested and homogenized in boiling Laemmli buffer. Cellular proteins were resolved by $5-15 \%$ SDS-PAGE and electrotransferred to a nitrocellulose membrane. The membrane was autoclaved for $30 \mathrm{~min}$ at $110^{\circ} \mathrm{C}$ to increase sensitivity of the assay and stained with rabbit polyclonal antiubiquitin antibodies (Sigma). Detection was performed with a chemiluminescence kit from Roche (Penzberg, Germany).

Proteosomal activity assays. Proteosomal activity was assayed as described previously ${ }^{42}$ with fractionation of cell lysates by ultrafiltration and gelfiltration to obtain proteasome rich fractions almost devoid of contaminating protease activities. Cell pellets or mouse brain tissues were homogenized in a buffer containing $50 \mathrm{mM}$ Tris- $\mathrm{HCl}, \mathrm{pH} 7.8,20 \mathrm{mM} \mathrm{KCl}, 0.5 \mathrm{mM}$ magnesium acetate, $1 \mathrm{mM}$ DTT (Buffer A) using a glass tube homogenizer. The homogenate was filtered through a three-layered cheesecloth to remove lipids and the filtrate was centrifuged at $12000 \times \mathrm{g}$ for $10 \mathrm{~min}$ at $4^{\circ} \mathrm{C}$. The supernatant was diluted 20 -fold in Buffer $\mathrm{A}$ containing $10 \%$ glycerol and $2 \mathrm{mM}$ ATP, concentrated to original volume using a polyethersulfone ultrafiltration membrane with a cutoff of $500 \mathrm{kDa}$ (Millipore, Bedford, MA, USA) and loaded on FPLC Superose 6 (Pharmacia Biotech) column eluted with the same buffer. One $\mathrm{ml}$ fractions were collected and assayed for tryptic and chymotryptic activities using N-Suc-LLVY-AMC (Biomol, Plymouth, PA, USA), Boc-LRR-AMC (Bachem, Bubendorf, Switzerland) and lactacystin inhibitor (Calbiochem) as described previously. ${ }^{42}$

UCH-L1 transfection studies and apoptosis detection. A pCMVSport6 vector containing the entire human UCH-L1 (PGP 9.5) CDNA was purchased from Invitrogen. To obtain a plasmid coding for UCH-L1-FLAG fusion protein, the CDNA was amplified using modified primers (AAGCTTATGCAGCTCAA GCCGATGG and CTCGAGGTAGGCTGCCTTGCAGAGAGC) containing flanking Hindll and Xhol sites. The Hindll//Xhol fragment was subcloned into pCMV-Tag 4a vector. The construct was entirely sequenced and expressed in COS-7 cells to ensure that FLAG-tagged protein retains catalytic activity. Normal skin fibroblasts were electroporated with $20 \mu \mathrm{g}$ of PCMV-UCH-L1-FLAG vector in MEM containing $1.25 \%$ (v/v) DMSO using Gene Pulser II apparatus (Bio-Rad) set at $290 \mathrm{~V}$ and $950 \mu \mathrm{F}(0.55 \mathrm{kV} / \mathrm{cm})$. At $24 \mathrm{~h}$ after transfection, the cells growing on glass slides were treated with $0.5 \mathrm{mM} \mathrm{E}-64$ for an additional $24 \mathrm{~h}$, fixed, stained with monoclonal anti-FLAG peptide antibodies/Texas Red-conjugated anti-mouse lgG antibodies (Molecular Probes, Eugene, OR, USA) and counter-stained for apoptosis using TUNEL (Fluorescein in situ Cell Death Detection) kit from Roche. Alternatively, prior to immunocytochemical studies cells were treated for $1 \mathrm{~h}$ with LysoTracker Red and counterstained with DAPI (Molecular Probes).

Quantification of UCH-L1 protein in cell homogenates and brain extracts by Western blotting. Cells from a confluent T-150 were harvested in PBS using a cell scraper. Cells were washed in PBS, lysed in water and sonicated $2 \times 10 \mathrm{~s}$. Proteins $(\sim 15 \mu \mathrm{g})$ were separated on a NuPAGE $4-12 \%$ Bis-Tris gel (Invitrogen). Transfer to a PVDF membrane was performed for $1.5 \mathrm{~h}$ at $150 \mathrm{~mA}$ using a semi-dry apparatus (Nova Blot, Pharmacia). The membrane was stained with Ponceau S then cut horizontally between the 50 and $37 \mathrm{kDa}$ markers. Blocking was carried out for $1 \mathrm{~h}$ in blotto (TBS $0.1 \%$ Tween- $202 \%$ milk). The upper part of the membrane was incubated overnight at $4^{\circ} \mathrm{C}$ with anti-GAPDH antibodies (Ambion, dilution 1:10000) and the lower part with anti-PGP 9.5 (UCH-L1) antibodies (NovoCastra, dilution 1:500). Detection was done using Roche Western kit for GAPDH and Millipore Immobilon kit for PGP 9.5.

Mouse whole brains were homogenized in $1 \mathrm{ml}$ of modified RIPA buffer $(150 \mathrm{mM}$ sodium chloride, $50 \mathrm{mM}$ Tris- $\mathrm{HCl}$, pH 7.4, 1 mM EDTA, 1\% Triton X-100, 1\% sodium deoxycholic acid, $0.1 \%$ SDS, $1 \mathrm{mM}$ PMSF) containing a complete protease inhibitor cocktail (Sigma) in glass tube homogenizer. The homogenate was centrifuged at $12000 \times g$ for $10 \mathrm{~min}$ at $4^{\circ} \mathrm{C}$ to remove any insoluble material. Protein samples were heated at $85^{\circ} \mathrm{C}$ for $5 \mathrm{~min}$ in $1 \times$ NuPAGE LDS sample buffer with reducing agent (Invitrogen). Detection of UCH-L1 in the mouse brains was performed in the cell homogenates with the following modifications: protein loading was $20 \mu \mathrm{g}$, antiPGP 9.5 antibodies were used at 1:1000 dilution and detection was done with the Roche Western kit.

Quantification of UCH-L1 protein in brain extracts by MS-based assay. Total brain tissues of HEXB $+1+$ and HEXB- $-1-$ mice were dissolved in Laemmli buffer and analyzed by SDS-PAGE. Gels were either stained with 
Coomassie Blue or transferred to a nitrocellulose membrane for Western blotting with anti-UCH-L1 antibodies. Gel pieces containing the UCH-L1-immunoreactive band were excised from the Coomassie-stained gels and subjected to tryptic digestion and peptide extraction. Samples were analyzed on ion-trap LC-MS/MS instrument (Nanoflow proteomic solution, Agilent). Spectra were interpreted and quantified using Spectrum Mill software (Agilent). Relative abundance of the protein in two samples was calculated as the ratio of the square roots of the Total Protein Spectra Intensities defined by the Spectrum Mill software as the sum of total intensities of all the peptides assigned to the protein. In turn, the Total Intensity of the peptide was calculated as the sum of the precursor ions abundances in the MS scans (see http://www.chem.agilent.com/scripts for details). From our independent study using 440 proteins in the cell extract, we have found that this parameter correlates well with the relative abundance measured with isotopic peptide mass tags or biochemically by Western blot or enzyme activity assay (M Fedjaev, paper in preparation). Unrelated proteins detected in the same gel pieces (triosephosphate isomerase, peroxiredoxin 6 and glutathione $S$-transferase) showed similar relative abundance in the samples taken from HEXB $+/+$ and HEXB- $/-$ animals.

UCH-L1 small interfering RNA gene silencing in human skin fibroblasts. Silencer ${ }^{\mathrm{TM}}$ pre-designed siRNA targeting exons 4 and 5 of the human UCH-L1 gene (Supplementary Table 2) were obtained from Ambion (Austin, TX, USA). Cultured skin fibroblasts were transfected with siRNA using the Lipofectamine Plus transfection kit (Invitrogen). GAPDH siRNA (Ambion) was used as a positive control for the optimization of transfection conditions. Prior to the experiments with normal control fibroblasts, the siRNA efficacy was verified using human skin fibroblasts immortalized by transduction with the retroviral vectors expressing the type 16 human papilloma virus E7 gene and the catalytic component of human telomerase (kindly provided by $\mathrm{E}$ Shoubridge, Montreal Neurological Institute). The cells were harvested 24 and $48 \mathrm{~h}$ after transfection with three UCH-L1 siRNAs, and UCH-L1 protein level was assessed by Western blot and immunocytochemistry as described above. Total RNA purified from a separate pool of the transfected cells was used to measure UCH-L1 mRNA level by quantitative real-time PCR. The most effective UCH-L1 siRNA (14311) was selected to perform the suppression experiments in the normal skin fibroblasts.

At $48 \mathrm{~h}$ after transfection of normal skin fibroblasts with the UCH-L1 siRNA (final concentration in culture medium $50 \mathrm{nM}$ ) the cells were fixed and permeabilized as described above. At $24 \mathrm{~h}$ after transfection a subset of UCH-L1-transfected and mock-transfected cells was also treated for $24 \mathrm{~h}$ with $0.5 \mathrm{mM} \mathrm{E}-64$. All cells were stained using a TUNEL kit as described above and counterstained for the UCH-L1 protein as described above. Programmed cell death was also detected using the sulforhodamine multicaspase activity kit from Biomol, containing a SR-VAD-FMK substrate of caspases-1 to -9 . For this, $48 \mathrm{~h}$ after transfection live cells were incubated for $1 \mathrm{~h}$ at $37^{\circ} \mathrm{C}$ with SR-VAD-FMK reagent as recommended by the manufacturer, washed, fixed and counterstained for the UCH-L1 protein.

\section{Detection of pro- and antiapoptotic proteins in the UCH-L1} siRNA-treated cells. The fibroblasts transfected with the UCH-L1 siRNA for 12,24 and $48 \mathrm{~h}$ and the mock-transfected controls were suspended in lysis buffer (10 mM Tris- $\mathrm{HCl}, 10 \mathrm{mM} \mathrm{NaCl}, 3 \mathrm{mM} \mathrm{MgCl}, 30 \mathrm{mM}$ sucrose, $\mathrm{pH} 7.4$ ) and homogenized with a glass homogenizer (300 strokes); the lysate was centrifuged at $700 \times g$ for $10 \mathrm{~min}$ at $4^{\circ} \mathrm{C}$ to remove nuclei and debris, and the supernatant recentrifuged at $10000 \times g$ for $15 \mathrm{~min}$ to obtain mitochondria-containing pellet. The supernatant was centrifuged again at $120000 \times g$ for $1 \mathrm{~h}$ to obtain the $S 100$ cytosolic fraction. The nuclear fraction was additionally purified by washing with the lysis buffer containing $0.12 \% \mathrm{NP}-40$ and centrifugation at $800 \times \mathrm{g}$ for $10 \mathrm{~min}$. Protein extraction was performed using $50 \mathrm{mM}$ Tris- $\mathrm{HCl}$, $\mathrm{pH} 7.4$, containing $1 \% \mathrm{NP}$ 40, 0.25\% Na-deoxycholate (Sigma), $150 \mathrm{mM} \mathrm{NaCl}, 1 \mathrm{mM}$ EDTA, $2 \mathrm{mM} \mathrm{Na}_{3} \mathrm{VO}_{4}$ (Sigma), $1 \mathrm{mM} \mathrm{NaF}$ and protease inhibitor cocktail (Roche). Protein (20 or $30 \mu \mathrm{g}$ ) from the total lysate, mitochondrial, nuclear or cytosol fractions were analyzed by SDS-PAGE. Proteins were transferred to PVDF membranes and probed with antibodies against Bax (clone 6A7 of Pharmingen and B-9 of Santa Cruz for the cleavage of Bax to generate p18 fragment), Bcl-2 (Pharmingen), p53 (clone Pab 240, NeoMarkers), cytochrome $c$ (Pharmingen), Bim (Calbiochem) and $\beta$-actin (Abcam). Intensities of the immuno-reactive bands were measured using Image Pro PlusSoftware (version 4.1.00) from Media Cybernetics.

Statistical methods. Statistical analysis was performed using the two-sample Wilcoxon test.
Acknowledgements. The authors thank the Genome Quebec Microarray Facility for the assistance in performing the microarray studies. This work was supported in part by an operating grant from the Canadian Institutes of Health Research MT-38107, a Genome Canada/Genome Quebec grant and by equipment grant from the Canadian Foundation for Innovation to AVP. PB acknowledges a predoctoral summer studentship from the Canadian Society for Mucopolysaccharide and Related Diseases. AVP is a National Investigator of FRSQ.

1. Zhan SS, Beyreuther K, Schmitt HP. Neuronal ubiquitin and neurofilament expression in different lysosomal storage disorders. Clin Neuropathol 1992; 11: 251-255.

2. Heuer GG, Passini MA, Jiang K, Parente MK, Lee VM, Trojanowski JQ et al. Selective neurodegeneration in murine mucopolysaccharidosis $\mathrm{VII}$ is progressive and reversible. Ann Neurol 2002; 52: 762-770.

3. Higashi Y, Murayama S, Pentchev PG, Suzuki K. Cerebellar degeneration in the NiemannPick type C mouse. Acta Neuropathol (Berl) 1993; 85: 175-184.

4. Oya Y, Nakayasu H, Fujita N, Suzuki K, Suzuki K. Pathological study of mice with total deficiency of sphingolipid activator proteins (SAP knockout mice). Acta Neuropathol (Berl) 1998; 96: 29-40.

5. Bonifacino JS, Traub LM. Signals for sorting of transmembrane proteins to endosomes and lysosomes. Annu Rev Biochem 2003; 72: 395-447.

6. Huang JQ, Trasler JM, Igdoura S, Michaud J, Hanal N, Gravel RA. Apoptotic cell death in mouse models of GM2 gangliosidosis and observations on human Tay-Sachs and Sandhoff diseases. Hum Mol Genet 1997; 6: 1879-1885.

7. Zhou J, Cox NR, Ewald SJ, Morrison NE, Basker HJ. Evaluation of GM1 gangliosidemediated apoptosis in feline thymocytes. Vet Immunol Immunopathol 1998; 66: 25-42.

8. Finn LS, Zhang M, Chen SH, Scott CR. Severe type II Gaucher disease with ichthyosis, arthrogryposis and neuronal apoptosis: molecular and pathological analyses. Am J Med Genet 2000; 91: 222-226.

9. Im DS, Heise CE, Nguyen T, O'Dowd BF, Lynch KR. Identification of a molecular target of psychosine and its role in globoid cell formation. J Cell Biol 2001; 153: 429-434.

10. Lozano J, Morales A, Cremesti A, Fuks Z, Tilly JL, Schuchman E et al. Niemann-Pick Disease versus acid sphingomyelinase deficiency. Cell Death Differ 2001; 8: 100-103.

11. Jatana M, Giri S, Singh AK. Apoptotic positive cells in Krabbe brain and induction of apoptosis in rat C6 glial cells by psychosine. Neurosci Lett 2002; 330: 183-187.

12. Cho S, Dawson PE, Dawson G. Role of palmitoyl-protein thioesterase in cell death: implications for infantile neuronal ceroid lipofuscinosis. Eur J Paediatr Neurol 2001; 5: 5355 .

13. Simonaro CM, Haskins ME, Schuchman EH. Articular chondrocytes from animals with a dermatan sulfate storage disease undergo a high rate of apoptosis and release nitric oxide and inflammatory cytokines: a possible mechanism underlying degenerative joint disease in the mucopolysaccharidoses. Lab Invest 2001; 81: 1319-1328.

14. Hesselink RP, Wagenmakers AJ, Drost MR, Van der Vusse GJ. Lysosomal dysfunction in muscle with special reference to glycogen storage disease type II. Biochim Biophys Acta 2003; 1637: 164-170.

15. Park M, Helip-Wooley A, Thoene J. Lysosomal cystine storage augments apoptosis in cultured human fibroblasts and renal tubular epithelial cells. J Am Soc Nephrol 2002; 13: 2878-2887.

16. Tardy C, Andrieu-Abadie N, Salvayre R, Levade T. Lysosomal storage diseases: is impaired apoptosis a pathogenic mechanism? Neurochem Res 2004; 29: 871-880.

17. Wada R, Tifft CJ, Proia RL. Microglial activation precedes acute neurodegeneration in Sandhoff disease and is suppressed by bone marrow transplantation. Proc Natl Acad Sci USA 2000; 97: 10954-10959.

18. Mizukami H, Mi Y, Wada R, Kono M, Yamashita T, Liu Y et al. Systemic inflammation in glucocerebrosidase-deficient mice with minimal glucosylceramide storage. J Clin Invest 2002; 109: 1215-1221.

19. Leroy E, Boyer R, Auburger G, Leube B, Ulm G, Mezey E et al. The ubiquitin pathway in Parkinson's disease. Nature 1998; 395: 451-452.

20. Phaneuf D, Wakamatsu N, Huang JQ, Borowski A, Peterson AC, Fortunato SR et al. Dramatically different phenotypes in mouse models of human Tay-Sachs and Sandhoff diseases. Hum Mol Genet 1996; 5: 1-14.

21. Choi J, Levey Al, Weintraub ST, Rees HD, Gearing M, Chin LS et al. Oxidative modifications and down-regulation of ubiquitin carboxyl-terminal hydrolase L1 associated with idiopathic Parkinson's and Alzheimer's diseases. J Biol Chem 2004; 279: 1325613264.

22. Doherty FJ, Osborn NU, Wassell JA, Heggie PE, Laszlo L, Mayer RJ. Ubiquitin-protein conjugates accumulate in the lysosomal system of fibroblasts treated with cysteine proteinase inhibitors. Biochem J 1989; 263: 47-55.

23. Laszlo L, Doherty FJ, Osborn NU, Mayer RJ. Ubiquitinated protein conjugates are specifically enriched in the lysosomal system of fibroblasts. FEBS Lett 1990; 261: 365-368.

24. Osaka H, Wang YL, Takada K, Takizawa S, Setsuie R, Li H et al. Ubiquitin carboxyterminal hydrolase L1 binds to and stabilizes monoubiquitin in neuron. Hum Mol Genet 2003; 12: 1945-1958.

25. Drexler HC. Activation of the cell death program by inhibition of proteasome function. Proc Natl Acad Sci USA 1997; 94: 855-860. 
26. Varshavsky A. The ubiquitin system. Trends Biochem Sci 1997; 22: 383-387.

27. Bence NF, Sampat RM, Kopito RR. Impairment of the ubiquitin-proteasome system by protein aggregation. Science 2001; 292: 1552-1555

28. Wilkinson KD, Lee KM, Deshpande S, Duerksen-Hughes P, Boss JM, Pohl J. The neuronspecific protein PGP 9.5 is a ubiquitin carboxyl-terminal hydrolase. Science 1989; 246 670-673.

29. Olerud JE, Chiu DS, Usui ML, Gibran NS, Ansel JC. Protein gene product 9.5 is expressed by fibroblasts in human cutaneous wounds. J Invest Dermatol 1998; 111: 565-572.

30. Saigoh K, Wang YL, Suh JG, Yamanishi T, Sakai Y, Kiyosawa H et al. Intragenic deletion in the gene encoding ubiquitin carboxy-terminal hydrolase in gad mice. Nat Genet 1999; 23 47-51.

31. Kurihara LJ, Kikuchi T, Wada K, Tilghman SM. Loss of Uch-L1 and Uch-L3 leads to neurodegeneration, posterior paralysis and dysphagia. Hum Mol Genet 2001; 10: 1963-1970.

32. Castegna A, Thongboonkerd V, Klein J, Lynn BC, Wang YL, Osaka $\mathrm{H}$ et al. Proteomic analysis of brain proteins in the cracile axonal dystrophy (gad) mouse, a syndrome that emanates from dysfunctional ubiquitin carboxyl-terminal hydrolase $L-1$, reveals oxidation of key proteins. J Neurochem 2004; 88: 1540-1546.

33. Fernandez-Funez P, Nino-Rosales ML, de Gouyon B, She WC, Luchak JM, Martinez P et al. Identification of genes that modify ataxin-1-induced neurodegeneration. Nature 2000; 408: 101-106.

34. Liu Y, Fallon L, Lashuel HA, Liu Z, Lansbury Jr PT. The UCH-L1 gene encodes two opposing enzymatic activities that affect alpha-synuclein degradation and Parkinson's disease susceptibility. Cell 2002; 111: 209-218.
35. Ardley HC, Scott GB, Rose SA, Tan NG, Robinson PA. UCH-L1 aggresome formation in response to proteasome impairment indicates a role in inclusion formation in Parkinson's disease. J Neurochem 2004; 90: 379-391.

36. Yang Y, Yu X. Regulation of apoptosis: the ubiquitous way. FASEB J 2003; 17: 790-799.

37. Kwon J, Wang YL, Setsuie R, Sekiguchi S, Sato Y, Sakurai M et al. Two closely related ubiquitin $\mathrm{C}$-terminal hydrolase isozymes function as reciprocal modulators of germ cell apoptosis in cryptorchid testis. Am J Pathol 2004; 165: 1367-1374.

38. Yamazaki T, Hibi K, Takase T, Tezel E, Nakayama H, Kasai Y et al. PGP9.5 as a marker for invasive colorectal cancer. Clin Cancer Res 2002; 8: 192-195.

39. Bonin M, Poths S, Osaka H, Wang YL, Wada K, Riess O. Microarray expression analysis of gad mice implicates involvement of Parkinson's disease associated UCH-L1 in multiple metabolic pathways. Brain Res Mol Brain Res 2004; 126: 88-97.

40. Harada T, Harada C, Wang YL, Osaka H, Amanai K, Tanaka K et al. Role of ubiquitin carboxy terminal hydrolase-L1 in neural cell apoptosis induced by ischemic retinal injury in vivo. Am J Pathol 2004; 164: 59-64.

41. Pshezhetsky AV, Potier M. Association of $\mathrm{N}$-acetylgalactosamine-6-sulfate sulfatase with the multienzyme lysosomal complex of beta-galactosidase, cathepsin $A$, and neuraminidase. Possible implication for intralysosomal catabolism of keratan sulfate. J Biol Chem 1996; 271: 28359-28365.

42. Rodgers KJ, Dean RT. Assessment of proteasome activity in cell lysates and tissue homogenates using peptide substrates. Int J Biochem Cell Biol 2003; 35: 716-727.

Supplementary Information accompanies the paper on Cell Death and Differentiation website (http://www.nature.com/cdd) 